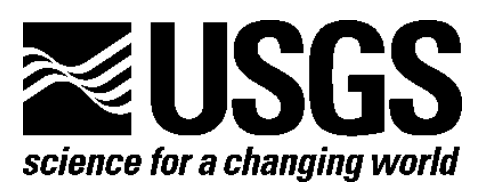

\title{
Abstracts for the October 2012 Meeting on Volcanism in the American Southwest, Flagstaff, Arizona
}

Edited By Jacob B. Lowenstern

Open-File Report 2013-1026

U.S. Department of the Interior

U.S. Geological Survey 


\section{U.S. Department of the Interior \\ KEN SALAZAR, Secretary}

\section{U.S. Geological Survey \\ Marcia K. McNutt, Director}

U.S. Geological Survey, Reston, Virginia: 2013

For product and ordering information:

World Wide Web: http://www.usgs.gov/pubprod

Telephone: 1-888-ASK-USGS

For more information on the USGS-the Federal source for science about the Earth, its natural and living resources, natural hazards, and the environment:

World Wide Web: http://www.usgs.gov

Telephone: 1-888-ASK-USGS

Suggested citation:

Lowenstern, Jacob B., ed., 2013, Abstracts for the October 2012 meeting on Volcanism in the American Southwest, Flagstaff, Arizona: U.S. Geological Survey Open-File Report 2013-1026, 39 p.

Any use of trade, product, or firm names is for descriptive purposes only and does not imply endorsement by the U.S. Government.

Although this report is in the public domain, permission must be secured from the individual copyright owners to reproduce any copyrighted material contained within this report. 


\section{Contents}

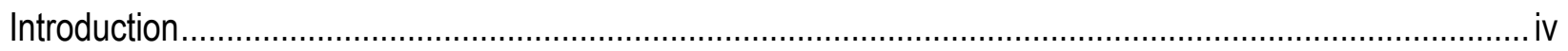

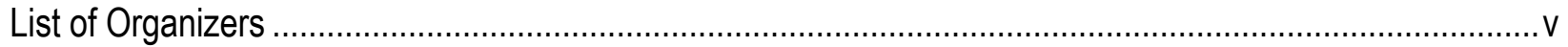

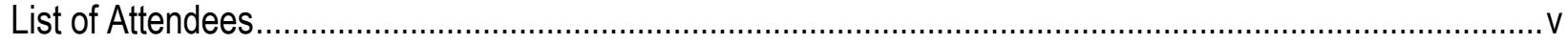

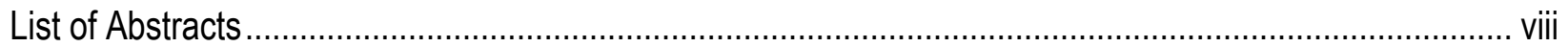

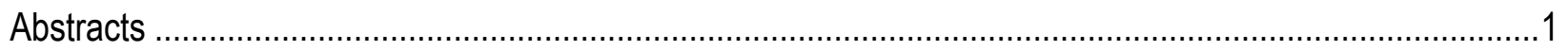

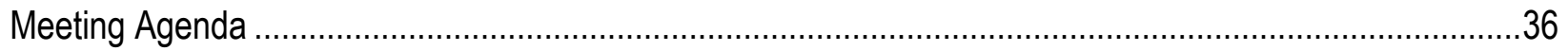

\section{Conversion Factors}

\begin{tabular}{lll}
\hline \multicolumn{1}{c}{ Multiply } & \multicolumn{1}{c}{ By } & \multicolumn{1}{c}{ To obtain } \\
\hline inch (in.) & 2.54 & centimeter $(\mathrm{cm})$ \\
foot (ft) & 0.3048 & meter $(\mathrm{m})$ \\
mile (mi) & 1.609 & kilometer $(\mathrm{km})$ \\
cubic foot per second (cfs) & 0.02832 & cubic meter per second $\left(\mathrm{m}^{3} / \mathrm{s}\right)$ \\
\hline
\end{tabular}




\title{
Abstracts for the October 2012 Meeting on Volcanism in the American Southwest, Flagstaff, Arizona
}

\author{
Edited by Jacob B. Lowenstern
}

\section{Introduction}

Though volcanic eruptions are comparatively rare in the American Southwest, the States of Arizona, Colorado, New Mexico, Nevada, and Utah host Holocene volcanic eruption deposits and are vulnerable to future volcanic activity. Compared with other parts of the western United States, comparatively little research has been focused on this area, and eruption probabilities are poorly constrained. Monitoring infrastructure consists of a variety of local seismic networks, and "backbone" geodetic networks with little integration. Emergency response planning for volcanic unrest has received little attention by either Federal or State agencies.

On October 18-20, 2012, 90 people met at the U.S. Geological Survey campus in Flagstaff, Arizona, providing an opportunity for volcanologists, land managers, and emergency responders to meet, converse, and begin to plan protocols for any future activity. Geologists contributed data on recent findings of eruptive ages, eruption probabilities, and hazards extents (plume heights, ash dispersal). Geophysicists discussed evidence for magma intrusions from seismic, geodetic, and other geophysical techniques. Network operators publicized their recent work and the relevance of their equipment to volcanic regions. Land managers and emergency responders shared their experiences with emergency planning for earthquakes.

The meeting was organized out of the recognition that little attention had been paid to planning for or mitigation of volcanic hazards in the American Southwest. Moreover, few geological meetings have hosted a session specifically devoted to this topic. This volume represents one official outcome of the meeting - a collection of abstracts related to talks and poster presentations shared during the first two days of the meeting. In addition, this report includes the meeting agenda as a record of the proceedings.

One additional intended outcome will be greater discussion and coordination among

emergency responders, geologists, geophysicists, and land managers regarding geologic hazards in the Southwest. 


\section{Meeting organizers}

Jacob B. Lowenstern, U.S. Geological Survey, Menlo Park, California

Laz Kestay, U.S. Geological Survey, Flagstaff, Arizona

Nelia Dunbar, New Mexico Bureau of Mines and Geology, Socorro, New Mexico

Michael Ort, Northern Arizona University, Flagstaff, Arizona

Greg Valentine, University at Buffalo, Buffalo, New York

Susan Perry, U.S. Geological Survey, Pasadena, California

John Bwarie, U.S. Geological Survey, Pasadena, California

\section{List of Attendees}

Alfano, Fabrizio, Arizona State University, Tempe, Arizona

Allison, Chelsea, Arizona State University, Tempe, Arizona

Aster, Rick, New Mexico Tech, Socorro, New Mexico

Aubele, Jayne, New Mexico Museum of Natural History and Science

Birch, Scott, National Weather Service, Salt Lake City, Utah

Bischoff, Judy, National Park Service, Flagstaff, Arizona

Blackwell, Wendy, New Mexico DHSEM Preparedness Bureau

Bowman, Steve, Utah Geological Survey, Salt Lake City, Utah

Brumbaugh, David, Northern Arizona University, Flagstaff, Arizona

Bwarie, John, USGS Pasadena, California (Science Applications for Risk Reduction)

Chamberlin, Richard, New Mexico Bureau of Geology, Socorro, New Mexico

Champion, Duane, USGS Menlo Park, California

Chung, Diane, National Park Service, Flagstaff, Arizona

Clarke, Amanda, Arizona State University, Tempe, Arizona

Connor, Chuck, University of South Florida, Tampa, Florida

Conway, Michael, Arizona Geological Survey, Tempe, Arizona

Cortes, Joaquin, University at Buffalo, Buffalo, New York

Courtland, Leah, University of South Florida, Tampa, Florida

Cousens, Brian, Carleton University, Ottawa, Canada

Crumpler, Larry, NM Museum of Natural History and Science

Driedger, Carolyn, USGS, Vancouver, Washington

Duffield, Wendell, Retired, Northern Arizona University, Flagstaff, Arizona

Dunbar, Nelia, New Mexico Tech, Socorro, New Mexico 
Earle, Paul, USGS National Earthquake Information Center (Denver, Colorado)

Elson, Mark, Desert Archaeology, Inc., Flagstaff, Arizona

Ewert, John, USGS, Vancouver, Washington

Finn, Carol, USGS, Denver, Colorado

Goff, Cathy, Retired, USGS, Losa Alamos, New Mexico

Goff, Fraser, Retired, Los Alamos National Laboratory, New Mexico

Greco, Deanna, National Park Service, Flagstaff, Arizona

Haller, Miguel, Univ. Nac. de Patagonia, Argentina

Hammond, Bill, University of Nevada, Reno

Harburger, Aleeza, University of South Florida, Tampa, Florida

Henry, Chris, Nevada Bureau of Mines and Geology, Reno, Nevada

Hintz, Amanda, Utah Geological Survey, Salt Lake City, Utah

Jackson, Christina, Coconino County Public Health Services District, Flagstaff, Arizona

Johnsen, Racheal, University of Nevada, Las Vegas

Johnson, Peter, University at Buffalo, Buffalo, New York

Judge, Shelley, College of Wooster, Wooster, Ohio

Karlstrom, Leif, Stanford University, Stanford, California

Kestay, Laz, USGS Flagstaff, Arizona

Kopcik, Ron, Arizona Division of Emergency Management, Tucson, Arizona

Koper, Keith, University of Utah, Salt Lake City, Utah

Kuentz, Dave, Miami University, Oxford, Ohio

Lee, Jeff, Coconino County Emergency Management, Flagstaff, Arizona

Lefebvre, Nathalie, University of Otago, Dunedin, New Zealand

Lorenz, Volker, University of Würzburg, Germany

Lowenstern, Jacob, USGS Menlo Park, California

McIntosh, Bill, New Mexico Tech, Socorro, New Mexico

Murray, Tom USGS Anchorage, Alaska

Neal, Tina, USGS Anchorage, Alaska

Norris, Bob, Retired Seismologist, Flagstaff, Arizona

Nushart, Nate, University of South Florida, Tampa, Florida

Ort, Michael, Northern Arizona University, Flagstaff, Arizona

Osiensky, Jeff, National Weather Service, Anchorage, Alaska

Penn, Ruthanne., Coconino County Emergency Management, Flagstaff, Arizona

Perry, Sue, USGS Pasadena, California (Science Applications for Risk Reduction)

Pollock, Meagen, College of Wooster, Wooster, Ohio

Poole, Jason, Federal Aviation Administration, Seattle, Washington 
Ramsey, Dave, USGS Vancouver, Washington

Richardson, Jacob, University of South Florida, Tampa, Florida

Riggs, Nancy, Northern Arizona University, Flagstaff, Arizona

Roggensack, Kurt, Arizona State University, Tempe, Arizona

Rowley, Robert L., Coconino County Emergency Management, Flagstaff, Arizona

Self, Steve, Nuclear Regulatory Commission, Alameda, California

Smith, Gene, University Nevada, Las Vegas, Nevada

Stanley, Ellis, Dewberry, Inc., Atlanta, Georgia

Stovall, Wendy, USGS Menlo Park, California

Taylor, Andrew, National Weather Service, Flagstaff, Arizona

Thompson, Katherine, Columbia University, New York, New York

Trammell, Darlene, Arizona Division of Emergency Management, Tucson, Arizona

Trammell, Lou, Arizona Division of Emergency Management, Tucson, Arizona

Turner, Jessica, USGS, National Earthquake Information Center, Denver, Colorado

Valentine, Greg, University at Buffalo, Buffalo, New York

Vaughan, Greg, USGS, Flagstaff, Arizona

Vazquez, Jorge, USGS, Menlo Park, California

Venzke, Ed, Smithsonian Global Volcanism Program, Washington, DC

White, James, University of Otago, Dunedin, New Zealand

Whitefield, Paul, Flagstaff Area National Monuments, Flagstaff, Arizona

Widom, Liz, Miami University of Ohio, Oxford, Ohio

Zimmerer, Matt, New Mexico Tech, Socorro, New Mexico 


\section{Volcanism in the American Southwest Abstracts}

Monitoring and Geophysics

\begin{tabular}{|l|l|l|l|l|}
\hline Page & Authors & Institution & Title & Type \\
\hline 2 & Aster et al. & $\begin{array}{l}\text { New Mexico } \\
\text { Tech }\end{array}$ & $\begin{array}{l}\text { Earthquakes in the Central Rio Grande Rift } \\
\text { and the Socorro Magma Body }\end{array}$ & $\mathrm{P}$ \\
\hline 4 & Brumbaugh & NAU & $\begin{array}{l}\text { Seismic monitoring of the San Francisco } \\
\text { volcanic field }\end{array}$ & $\mathrm{P}$ \\
\hline 16 & Hammond & $\begin{array}{l}\text { U. Nevada } \\
\text { Reno }\end{array}$ & $\begin{array}{l}\text { Potential contributions of geodesy to } \\
\text { monitoring volcanic unrest in the southwest } \\
\text { United States }\end{array}$ & $\mathrm{O}$ \\
\hline 22 & Koper et al. & U. Utah & $\begin{array}{l}\text { Capabilities of University of Utah } \\
\text { Seismograph Stations for monitoring } \\
\text { seismicity in Utah }\end{array}$ & $\mathrm{P}$ \\
\hline Lu et al. & USGS & $\begin{array}{l}\text { InSAR mapping of Holocene volcanoes in } \\
\text { the western conterminous U.S. - preliminary } \\
\text { results }\end{array}$ & $\mathrm{P}$ \\
\hline
\end{tabular}

\section{Communications and Mitigation}

\begin{tabular}{|c|c|c|c|c|}
\hline 10 & $\begin{array}{l}\text { Crumpler et } \\
\text { al. }\end{array}$ & $\begin{array}{l}\text { New Mexico } \\
\text { Museum of } \\
\text { Natural } \\
\text { History and } \\
\text { Science }\end{array}$ & $\begin{array}{l}\text { The New Mexico volcano collection and } \\
\text { resource: Volcanoes of New Mexico website } \\
\text { developed by the New Mexico Museum of } \\
\text { Natural History and Science }\end{array}$ & $\mathrm{P}$ \\
\hline 11 & Driedger & USGS & $\begin{array}{l}\text { Volcano work groups and effective } \\
\text { communication partnerships for volcanic } \\
\text { hazards education }\end{array}$ & $\mathrm{P}$ \\
\hline 13 & $\begin{array}{l}\text { Elson and } \\
\text { Ort }\end{array}$ & $\begin{array}{l}\text { Desert } \\
\text { Archaeology, } \\
\text { Inc. }\end{array}$ & $\begin{array}{l}\text { Human adaptation to catastrophic events: } \\
\text { Lessons from the } 11^{\text {th }} \text { Century CE eruption } \\
\text { of Sunset Crater volcano }\end{array}$ & $\mathrm{O}$ \\
\hline 24 & Neal & USGS & $\begin{array}{l}\text { Pondering the consequences of an eruption } \\
\text { in the American Southwest: Challenges for } \\
\text { emergency management and scientific } \\
\text { response }\end{array}$ & $\mathrm{O}$ \\
\hline 25 & $\begin{array}{l}\text { Osiensky } \\
\text { and Birch }\end{array}$ & NOAA/NWS & $\begin{array}{l}\text { Volcanic ash plumes and impact to aviation } \\
\text { in the western United States }\end{array}$ & $\mathrm{O}$ \\
\hline 26 & $\begin{array}{l}\text { Ramsey and } \\
\text { Driedger }\end{array}$ & USGS & $\begin{array}{l}\text { Spatial database of Holocene and Latest } \\
\text { Pleistocene volcanic vents in the western } \\
\text { conterminous U.S. }\end{array}$ & \\
\hline 29 & Thompson & Columbia U. & $\begin{array}{l}\text { The view from Social Science: How people } \\
\text { will think and behave during an extended } \\
\text { crisis with large uncertainties. }\end{array}$ & $\mathrm{O}$ \\
\hline
\end{tabular}




\begin{tabular}{|l|l|l|l|l|}
\hline 32 & Venzke & Smithsonian & $\begin{array}{l}\text { Data compiled by the Smithsonian about } \\
\text { volcanoes in the southwestern United States }\end{array}$ & $\mathrm{P}$ \\
\hline
\end{tabular}

\section{Geology}

\begin{tabular}{|c|c|c|c|c|}
\hline 1 & Alfano et al. & $\begin{array}{l}\text { Arizona State } \\
\text { Univ. }\end{array}$ & $\begin{array}{l}\text { Characterization of the } 1000 \text { AD Sunset } \\
\text { Crater eruption and its pyroclastic products }\end{array}$ & $\mathrm{P}$ \\
\hline 3 & $\begin{array}{l}\text { Bleacher et } \\
\text { al. }\end{array}$ & $\begin{array}{l}\text { NASA } \\
\text { Goddard }\end{array}$ & $\begin{array}{l}\text { Surface textures and relationships indicative } \\
\text { of endogenous growth at the McCartys and } \\
\text { Carrizozo flow fields, New Mexico }\end{array}$ & $\mathrm{P}$ \\
\hline 5 & $\begin{array}{l}\text { Chamberlin } \\
\text { et al. }\end{array}$ & $\begin{array}{l}\text { New Mexico } \\
\text { Tech }\end{array}$ & $\begin{array}{l}\text { Ignimbrite calderas and a large radiating } \\
\text { mafic dike swarm of Oligocene age, Rio } \\
\text { Grande Rift, New Mexico: Possible } \\
\text { implications to restless calderas }\end{array}$ & $\mathrm{P}$ \\
\hline 6 & Cortés et al. & U. Buffalo & $\begin{array}{l}\text { Intrinsic conditions of magmas in Lunar } \\
\text { Crater Volcanic Field, Nevada }\end{array}$ & $\mathrm{P}$ \\
\hline 7 & $\begin{array}{l}\text { Courtland et } \\
\text { al. }\end{array}$ & $\begin{array}{l}\text { University } \\
\text { South Florida }\end{array}$ & $\begin{array}{l}\text { Into the cone: a ground penetrating radar } \\
\text { study of cone-building processes at Cerro } \\
\text { Negro volcano, Nicaragua }\end{array}$ & $\mathrm{P}$ \\
\hline 8 & $\begin{array}{l}\text { Cousens } \\
\text { and Henry }\end{array}$ & Carleton Univ. & $\begin{array}{l}\text { Geochemistry and hazard assessment of } \\
\text { Pliocene-Quaternary volcanism beneath the } \\
\text { central Sierra Nevada and adjacent Great } \\
\text { Basin, northern California and western } \\
\text { Nevada }\end{array}$ & $\mathrm{P}$ \\
\hline 9 & $\begin{array}{l}\text { Crumpler et } \\
\text { al. }\end{array}$ & $\begin{array}{l}\text { New Mexico } \\
\text { Museum of } \\
\text { Natural } \\
\text { History and } \\
\text { Science }\end{array}$ & $\begin{array}{l}\text { Environmental consequences of large } \\
\text { volume lava flow fields in the southwest: } \\
\text { Preliminary inferences from mapping the } \\
\text { McCartys lava flow field, New Mexico }\end{array}$ & $\mathrm{P}$ \\
\hline 12 & $\begin{array}{l}\text { Dunbar and } \\
\text { McIntosh }\end{array}$ & $\begin{array}{l}\text { New Mexico } \\
\text { Tech }\end{array}$ & $\begin{array}{l}\text { Volcanism in New Mexico: Past activity and } \\
\text { future expectations: Zuni-Bandera volcanic } \\
\text { field, Valles caldera, Socorro magma body, } \\
\text { and beyond }\end{array}$ & $\mathrm{O}$ \\
\hline 14 & Goff & UNM & $\begin{array}{l}\text { Eruption potential and hazard, Valles } \\
\text { Caldera, New Mexico }\end{array}$ & $\mathrm{O}$ \\
\hline 15 & $\begin{array}{l}\text { Haller and } \\
\text { Frumento }\end{array}$ & $\begin{array}{l}\text { Univ. Nacional } \\
\text { de la Patagonia }\end{array}$ & $\begin{array}{l}\text { Estimating remobilization rate of ash } \\
\text { deposited during the Puyehue (Southern } \\
\text { Andes) eruption in } 2011\end{array}$ & $\mathrm{P}$ \\
\hline 17 & $\begin{array}{l}\text { Henry and } \\
\text { Cousens }\end{array}$ & $\begin{array}{l}\text { NV Bureau of } \\
\text { Mines and } \\
\text { Geology }\end{array}$ & $\begin{array}{l}\text { Young volcanism of the Lake Tahoe-Reno- } \\
\text { Fallon area, California and Nevada: The } \\
\text { geologic record }\end{array}$ & $\mathrm{P}$ \\
\hline 18 & $\begin{array}{l}\text { Johnson et } \\
\text { al. }\end{array}$ & U. Buffalo & $\begin{array}{l}\text { Tephra dispersal and deposition from the } \\
\text { Marcath eruption, Lunar Crater volcanic } \\
\text { field, Nevada }\end{array}$ & $\mathrm{P}$ \\
\hline
\end{tabular}




\begin{tabular}{|l|l|l|l|l|}
\hline 19 & $\begin{array}{l}\text { Karlstrom } \\
\text { et al. }\end{array}$ & Stanford Univ. & $\begin{array}{l}\text { Focusing of melt by magma chambers in } \\
\text { time and space: Theory and application to } \\
\text { Mount Mazama, Crater Lake, Oregon }\end{array}$ & P \\
\hline 20 & Keszthelyi & USGS & $\begin{array}{l}\text { Modeling mafic lava flows with an eye to } \\
\text { emergency response }\end{array}$ & O \\
\hline 21 & $\begin{array}{l}\text { Kiyosugi et } \\
\text { al. }\end{array}$ & $\begin{array}{l}\text { U. South } \\
\text { Florida }\end{array}$ & $\begin{array}{l}\text { Relationship between dike and volcanic } \\
\text { conduit distribution in a highly eroded } \\
\text { monogenetic volcanic field: San Rafael, } \\
\text { Utah }\end{array}$ & P \\
\hline 27 & $\begin{array}{l}\text { Roggensack } \\
\text { and Moore }\end{array}$ & ASU & $\begin{array}{l}\text { Experimental determination of } \mathrm{H}_{2} \mathrm{O} \text { and } \mathrm{CO}_{2} \\
\text { solubility in basalt and basaltic andesite }\end{array}$ & $\mathrm{P}$ \\
\hline 28 & Self & NRC & $\begin{array}{l}\text { Scenario for an eruption in the San } \\
\text { Francisco Peaks or similar volcanic field: } \\
\text { Effects on northern Arizona and beyond }\end{array}$ & O \\
\hline 30 & $\begin{array}{l}\text { Valentine } \\
\text { and Ort }\end{array}$ & U. Buffalo & $\begin{array}{l}\text { Basaltic volcanism in the American } \\
\text { Southwest over the last million years: What } \\
\text { happens here, how often, and why? }\end{array}$ & O \\
\hline 31 & $\begin{array}{l}\text { Vazquez et } \\
\text { al. }\end{array}$ & USGS & $\begin{array}{l}\text { Timing of late Pleistocene volcanism at Big } \\
\text { Pine volcanic field: insights from volcanic } \\
\text { stratigraphy, cosmogenic }{ }^{36} \text { Cl dating and } \\
\text { paleomagnetism. }\end{array}$ & P \\
\hline 33 & White & Otago, NZ & $\begin{array}{l}\text { Uncertainties regarding explosive maar- } \\
\text { diatreme eruptions within volcanic fields }\end{array}$ & P \\
\hline 34 & $\begin{array}{l}\text { Widom et } \\
\text { al. }\end{array}$ & $\begin{array}{l}\text { Miami U. } \\
\text { (OH) }\end{array}$ & $\begin{array}{l}\text { Petrogenetic processes in the Lunar Crater } \\
\text { volcanic field, Nevada }\end{array}$ & P \\
\hline 35 & $\begin{array}{l}\text { Zimmerer } \\
\text { and } \\
\text { McIntosh }\end{array}$ & $\begin{array}{l}\text { New Mexico } \\
\text { Tech }\end{array}$ & $\begin{array}{l}\text { Postcaldera magmatism at three Rio- } \\
\text { Grande-rifted calderas: Implications for } \\
\text { assessing volcanic hazards at active caldera } \\
\text { systems in the USA }\end{array}$ & P \\
\hline
\end{tabular}




\title{
Characterization of the 1000 AD Sunset Crater eruption and its pyroclastic products
}

\author{
Fabrizio Alfano ${ }^{1}$, Laura Pioli ${ }^{2}$, Amanda Clarke $^{1}$, Michael Ort ${ }^{3}$, Stephen Self ${ }^{3}$ \\ 1. School of Earth and Space Exploration (Arizona State University, USA); 2. Department of Mineralogy \\ (University of Geneva, Switzerland); 3. Department of Environmental Sciences and Geology (North Arizona \\ University, USA); 4. CEPSAR (The Open Universty, UK).
}

Sunset Crater is a $>300 \mathrm{~m}$ high scoria cone located $\sim 25 \mathrm{~km}$ northeast of Flagstaff, AZ (USA). It is the youngest of about 600 scoria cones in the San Francisco Volcanic Field and the only one active in the Holocene (1064-1067 A.D.). The eruption produced three lava flows that cover $\sim 8 \mathrm{~km}^{2}$, a scoria blanket up to $12 \mathrm{~m}$ thick covering an area of about $500 \mathrm{~km}^{2}$, and minor spatter cones and ramparts that marked the onset of the eruption (Amos, 1986; Ort et al., 2008). Pre-historical communities living in the area were heavily influenced by the eruption (Ort et al., 2008). The tephra sequence, as described in Amos (1986), consists of at least eight fall units associated with major explosive phases. The units are generally lithic poor, well sorted, non-welded, even at proximal locations, and inversely graded, with an average bulk density of about $1.5 \times 10^{3} \mathrm{~kg} / \mathrm{m}^{3}$, dispersed to the $\mathrm{E}$ and $\mathrm{W}$ (Amos 1986). Additional fieldwork conducted in September 2010 has pointed to more complexity than previously presented. In proximal areas, the sequence also includes cm-thick coarse ash layers, and multiple layering within the main units. These complexities may explain bilobate dispersal patterns exhibited by some of the original stratigraphic units (Amos, 1986). Their volume was estimated using the Weibull fitting method (Bonadonna and Costa 2011) and varies between 0.02 and $0.08 \mathrm{~km}^{3}$ DRE, with the maximum value estimated for the Unit 3 deposit $\left(0.08 \mathrm{~km}^{3} \mathrm{DRE}\right)$ and the total cumulative volume is estimated to be $0.3 \mathrm{~km}^{3}$ DRE. This value is close to the volume calculated based on the total deposit isopach map from Ort et al (2008) $\left(0.4 \mathrm{~km}^{3}\right.$ DRE). The associated column heights calculated using the Carey and Sparks (1986) method, based on the maximum clast distribution of Amos (1986), are between $7 \mathrm{~km}$ (Unit 2) and $25 \mathrm{~km}$ (Unit 3). These values have a high degree of uncertainty due to a paucity of data preventing good constraints on isopleths maps. Scoria clasts are porphyritic with the main phenocryst assemblage consisting of plagioclase, olivine and rare clinopyroxene crystals with longest axis to up to $0.5 \mathrm{~mm}$, and variable groundmass crystallinity (plagioclase, olivine and Fe oxides), ranging from glassy to almost completely crystalline. They show only minor compositional variations along the sequence. The variability can be relevant both within and among clasts, but the largest percentages of glassy scoria are associated with the largest fallout units. Scoria vesicles are rounded to elongated with diameters up to $1 \mathrm{~mm}$, and often show non-homogeneous distribution suggesting post-fragmentation expansion and coalescence. Olocrystalline clasts also display a diffuse vesicularity characterized by small vesicles (hundreds to tens of microns) with shapes controlled by the surrounding crystals. Large xenocrysts of pyroxene characterized by rounded morphologies and reaction rims are frequently observed.

\section{$\underline{\text { References }}$}

Amos, R.C., 1986, Sunset Crater, Arizona-evidence for a large magnitude strombolian eruption: M.S. thesis, Arizona State University, Tempe, $165 \mathrm{p}$.

Bonadonna C, Costa A (2012) Estimating the volume of tephra deposits: a new simple strategy, Geology, doi: 10.1130/G32769.1

Carey, S. N. and R. S. J. Sparks (1986). Quantitative models of the fallout and dispersal of tephra from volcanic eruption columns. Bulletin of Volcanology 48: 109-125.

Ort, M. H., M. D. Elson, K. C. Anderson, W. A. Duffield, J. A. Hooten, D. E. Champion and G. Waring (2008). Effects of scoriacone eruptions upon nearby human communities. Geological Society of America Bulletin 120(3-4): 476-486. 


\title{
Earthquakes in the Central Rio Grande Rift and the Socorro Magma Body
}

\author{
Richard Aster, Susan Bilek, Jana Stankova, Emily Morton \\ Department of Earth and Environmental Science
}

New Mexico Institute of Mining and Technology

Socorro, NM 87801

The Socorro Seismic Anomaly (SSA), occupies just $2 \%\left(\sim 5,000 \mathrm{~km}^{2}\right)$ of the area of New Mexico but is responsible for $20-40 \%$ of magnitude $\geq 2.0$ events in the 60 -year instrumental record. This relatively high rate of seismicity is due to the presence of an inflating ( $2 \mathrm{~mm} /$ year maximal surface uplift), predominantly thin, mid-crustal magma body (the Socorro Magma Body; SMB) with an upper surface at $\sim 19 \mathrm{~km}$ depth. The SMB bears similarities to other interpreted magmatic seismic "bright spots", such as one noted from COCORP studies near Death Valley as well as others in the Basin and Range province. Reflected phases of microearthquake seismograms recorded above the SSA and COCORP active seismic studies were initially used to define the depth and the extent of this feature. More recently, InSAR studies confirmed and refined the boundaries of the associated uplift. Over the last few decades many hundreds of magnitude $\geq 2.0$ earthquakes have been recorded in the SSA. The largest events in the historical record occurred in 1906 as part of a protracted (multi-year) swarm, and have been estimated to about magnitude 5.8. Typically, notable earthquake events in the SSA occur as a part of a seismic swarm lasting few days to a few weeks. Only about 1-3 events from such sequences are typically felt and reach magnitude $\geq 2.0$. As expected in a rifting environment, most of these events represent movement along normal faults, sometimes with a strike-slip component. Recent volcanism in the region (e.g., the Carrizozo Lava Flows) as young as 5,000 years indicates the possibility of basaltic volcanism associated with this feature, and the extraordinary flatness of the upper SMB surface is consistent with such a low viscosity composition. An alternative possibility is that the SMB is an active, primarily sill-like mafic intrusion that will ultimately solidify in the mid-crust without erupting. The long-standing seismicity above the $S M B$, including events as shallow as $\sim 2 \mathrm{~km}$, suggests that amagmatic migration of hydrothermal fluids and uplift accommodation can be expected to generate earthquakes above such features, which may make it difficult to definitively track the ascent of smaller volumes of magma from depth in an eruptive scenario. We present a summary of present knowledge of the SMB and its seismicity and uplift in a volcanological context. 


\title{
SURFACE TEXTURES AND RELATIONSHIPS INDICATIVE OF ENDOGENOUS GROWTH AT THE MCCARTYS AND CARRIZOZO FLOW FIELDS, NEW MEXICO
}

\author{
J. E. BLEACHER ${ }^{1}$, L. S. CRUMPLER ${ }^{2}$, W. B. GARRY ${ }^{3}$ ， J. R. ZIMBELMAN ${ }^{4}$, S. SELF ${ }^{5}$ and J. C. AUBELE ${ }^{2}$.
}

${ }^{1}$ NASA Goddard Space Flight Center, Planetary Geodynamics Laboratory, Greenbelt, MD, 20771, jacob.e.bleacher@nasa.gov,

${ }^{2}$ New Mexico Museum of Natural History \& Science, Albuquerque, NM, ${ }^{3}$ Planetary Science Institute, Tucson, AZ, ${ }^{4}$ Smithsonian Institution, National Air and Space Museum, ${ }^{5}$ Dept. of Earth and Environmental Sciences, The Open University, UK

Introduction: Basaltic lavas are well known to form channels or tubes during emplacement. However, the importance of sheet flow and inflation within basaltic terrains only received recognition over the last 10-20 years. Here we discuss evidence for endogenous growth of the McCartys and Carrizozo flow fields, NM. We focus on the distal margins of each field where the flows progressed over near zero degrees slopes, or in the southwest portion of the McCartys flow even progressed up hill over slopes $<1$ degree.

Textures and Relationships: The McCartys lava flow field is among the youngest ( 3000 yrs $)$ [1] basaltic lava flows in the continental United States whereas the Carrizozo is estimated to be $\sim 5000$ years old $[2,3]$. Both features are located within an arid environment, which combined with their age results in a display of pristine textures and unit relationships. The southwest sections of both flows display smooth, flat-topped plateaus with irregularly shaped pits and hummocky inter-plateau units that form a polygonal surface.

Plateaus are typically elongate in map view, up to 20 $\mathrm{m}$ high and display lineations within the glassy crust. Lineated surfaces occasionally display small $<1 \mathrm{~m}$ diameter lava coils. Lineations are generally straight and parallel each other, somtimes for many 10 s to over 100 meters. The boundaries between plateaus and depressions are also lineated and tilted to angles sometimes approaching vertical. Plateau-parallel cracks, sometimes containing squeeze-ups, mark the boundary between tilted crust and plateau. Some plateau depressions display level floors with hummocky surfaces, while some are bowl shaped with floors covered in broken lava slabs. Infrequently, pit floors display the upper portion of a tumulus from an older flow.

In some places the surface crust has been disrupted forming a slabby texture. Slabs are typically on the scale of a meter or less across and no less than 7-10 cm thick. The slabs preserve the lineated textures of the undisturbed plateau crust.

Interpretation \& Implications: We interpret the southwest portions of both flow fields to have experienced lava flow inflation. The lineated texture appears to represent the primitive emplacement of a laterally extensive sheet flow. Lineations likely form as shear zones within the sheet [4], occasionally forming coils [5]. The parallel nature of lineations suggest single active sheets during emplacement. Slabs indicate disruption of the original crust [6]. Unlike platy-ridge flows [7], these slabby units are confined to several meter diameter patches across the plateaus. As such, they did not involve extensive lateral transport. We suggest that disruption occurs as the sheet flow stagnates and inflation begins, perhaps cycling through minor localized deflation/inflation events, resulting in patchy, slabby terrain . Once the crust reached a thickness of $7-10 \mathrm{~cm}$, or 75 to 120 mins of cooling and crust formation (inverse Hon et al. [4] cooling equation [8]), the surface was generally capable of supporting sheetwide inflation without crust disruption. In places where the liquid sheet was thin due to flow around or over pre-existing topography, hindered- or non-inflation occurs, resulting in the formation of pits.

The Carrizozo displays delta-shaped slabby units that were breakout points from one sheet lobe to feed the next sheet lobe. In this case, lateral transport of crust likely contributed to disruption and is the closest morphology we see to platy-ridge. Not all outbreaks form slabby deltas, but we have begun using measurements of lineation trends to map out the direction of flow. Thus, we hope to continue mapping the flow emplacement history among lobes. Some breakouts do not feed substantially inflated sheets. Often these flows form the polygonal, hummocky terrain.

We present two interesting implications. First, the McCartys flow appears to have up a gentle slope to the $\mathrm{SW}$. The mechanism for this process likely involved the emplacement of an elongate sheet against the dip of the preexisting surface. If inflated, the lobe creates a trough against the rising slope. The next breakout fills this trough and enables the flow field to generally "step" upslope. Second, the development of disrupted crust creates a rough texture that might be misinterpreted as a'a lava. However, the process described above is fundamentally different from the formation of an a a flow, or even a platy ridge surface that involves lateral transport of the crust. As such, it might be critical to conduct facies-style mapping of lava flow textures, particularly in planetary data, if those textures are used to constrain emplacement conditions.

References: [1] Laughlin et al. (1994) Geology, 22, 135138. [2] Anthony E. Y. et al. (1998) New MexicoGeol. Soc. Guidebook, 117-122. [3] Dunbar N. W. (1999) New Mexico Geology, 21, 25-29. [4] Hon et al., (1994) GSA Bulletin 106, 351-370. [5] Peck (1966) USGS PP 550-B, 148-151. [6]

Wentworth \& Macdonald, (1953) USGS Bull, 994, 1-98. [7] Keszthelyi et al., Platy-ridge, [8] Keszthelyi et al. (2004), GGG, 5, 1-32. 


\title{
Seismic monitoring of the San Francisco volcanic field
}

\author{
David S. Brumbaugh \\ Arizona Earthquake Information Center
}

The northern Arizona Seismic network was created in 1985 to fill a need for seismic monitoring of the earthquake activity in Arizona, particularly for the active belt of seismicity on the Colorado Plateau stretching from Utah south to the plateau rim. Contained within the northern Arizona seismic belt (NASB) is the largest urban center, Flagstaff and also the San Francisco volcanic field classified as active by the U.S.G.S.

The geoscope program which occupied sites in Arizona 2006-2008 demonstrated the potential for a better understanding of Arizona seismicity by more extensive monitoring than had been possible in the past. As part of this program when Geoscope moved east of Arizona, A consortium of the three state universities in coordination with the Arizona Geological survey obtained funding from FEMA for purchase of eight geoscope stations, which when combined with the short period northern Arizona network formed a new statewide net now termed the Arizona Integrated Seismic Network (AISN). The sixeen station network in combination with other national stations at Wupatki, Tucson, Painted Desert and Organ Pipe has resulted in a lowering of the threshold for catalogue completeness in the state and therefore allowed an increase in detection of small magnitude swarms that could not be previously identified and located.

Earthquakes have occurred throughout historic time in the San Francisco volcanic field (1892present). Due to the lack of stations in the volcanic field and around it, only less frequent larger events could be identified and located until the advent of AISN. Two permanent AISN stations lie within the volcanic field (FLAG and WMZ) while others are near and around it providing additional coverage (GCAZ, CCAZ, X16A, X18A, U15A). Data from the national station WUAZ is often critical.

Two swarms of interest within the volcanic field have been located within the last three years by the AISN network. The 2009 Halloween swarm occurred over a six hour period on October 31 and had some characteristics that when compared to swarms related to eruptive activity elsewhere suggested a potential volcanogenic source. The events, at mid-crustal depths were aligned in a NE-SW trend between FLAG and WUAZ to the west of Sunset Crater.

The June 2011 swarm just south of Flagstaff occurred near the Anderson Mesa fault and when added to previous activity near the fault suggests that it poses a seismic hazard to the Flagstaff urban area. This swarm has characteristics not unlike that of other swarms in the state which differ from the Halloween swarm. 


\section{Ignimbrite Calderas and a Large Radiating Mafic Dike Swarm of Oligocene Age, Rio Grande Rift, New Mexico: Possible Implications to Restless Calderas}

R. M. Chamberlin ${ }^{1}$, W.C. McIntosh ${ }^{1}$, N.W. Dunbar ${ }^{1}$ and M. I. Dimeo ${ }^{2}$ ' ${ }^{1}$ New Mexico Bureau of Geology and Mineral Resources, New Mexico Tech, Socorro NM, $87801{ }^{2}$ Evolving Gold Corp., Longmont, CO 80501

The Oligocene Socorro-Magdalena magmatic system (SMMS, $7000 \mathrm{~km}^{3}$; Fig.1) of the early Rio Grande rift is expressed by three domains: 1) a cluster of 6 large rhyolitic calderas (Socorro-Magdalena caldera cluster, SMCC) at the core, 2) a medial apron of basaltic-andesite lavas $\left(1500 \mathrm{~km}^{3}\right)$ with intertonguing ignimbrite sheets, and 3) a large diameter $(200 \mathrm{~km})$ radial swarm of dominantly basaltic-andesite dikes (Magdalena radial dike swarm, MRDS) broadly focused on the SMCC. Closely spaced mafic dikes near Riley (n 100) strike NNW to NNE, essentially parallel to the Oligocene rift axis as defined by domino-style early rift faults in the Lemitar Mountains (Fig.1). Most dikes near Riley exhibit minimal contact metamorphism and are interpreted as non-eruptive dikes. Non-eruptive dikes also contain abundant magmatic carbonate (from trapped $\mathrm{CO}_{2}$ ) that has deuterically replaced sparse olivine and clinopyroxene phenocrysts. Three eruptive (feeder) dikes near Riley exhibit 10-20 m wide contact metamorphic aureoles that indicate strong heating of wall rocks hundreds of meters below where the dike once fed a basaltic volcano. Feeder dikes contain relatively fresh olivine basalt, which implies they lost $\mathrm{CO}_{2}$ during eruption. Close spacing and relative abundance of mafic dikes at Riley is attributed to local coincidence of outward (northward) magmatic pressures and westward extension of the early Rio Grande rift (i.e. magmatic $\sigma_{3}$ and tectonic $\sigma_{3}$ were both eastwest ).

Four long dikes of the MRDS — at Pie Town, Hickman, Jones Camp and Ft. McRae (Fig.1) — yield reasonably precise ${ }^{40} \mathrm{Ar} /{ }^{39} \mathrm{Ar}$ ages (0.4-1.0\% error) analytically equivalent to the large volume $\left(1250 \mathrm{~km}^{3}\right)$ La Jencia Tuff erupted from the Sawmill Canyon caldera at $29.1 \mathrm{Ma}(0.3 \%$ error $)$. Near horizontal flow lineations on the chilled margin of the Hickman dike $\left(\sim 15 \mathrm{~km}^{3}\right)$ and relatively precise age data suggest that it propagated northward during a period of high magma pressure shortly before caldera-forming eruption of the La Jencia Tuff (Fig.2). Our cross sectional model suggests that during periods of high magma pressure (precaldera tumescence) large volumes of relatively fluid basaltic magma were driven into fractures that propagated as much as $100 \mathrm{~km}$ outward from a lower crustal basaltic sill complex that fueled the caldera cluster (Figs. 1\& 2). A restless caldera, such as Yellowstone, that experiences a noneruptive earthquake swarm propagating several tens of km outward, over a few days, and in an odd direction relative to regional tectonic extension, may be indicative of a large volume magmatic system under extreme magmatic pressure (i.e. precaldera tumescence).

Supporting documents are available at http://geoinfo.nmt.edu/staff/chamberlin/mrds/

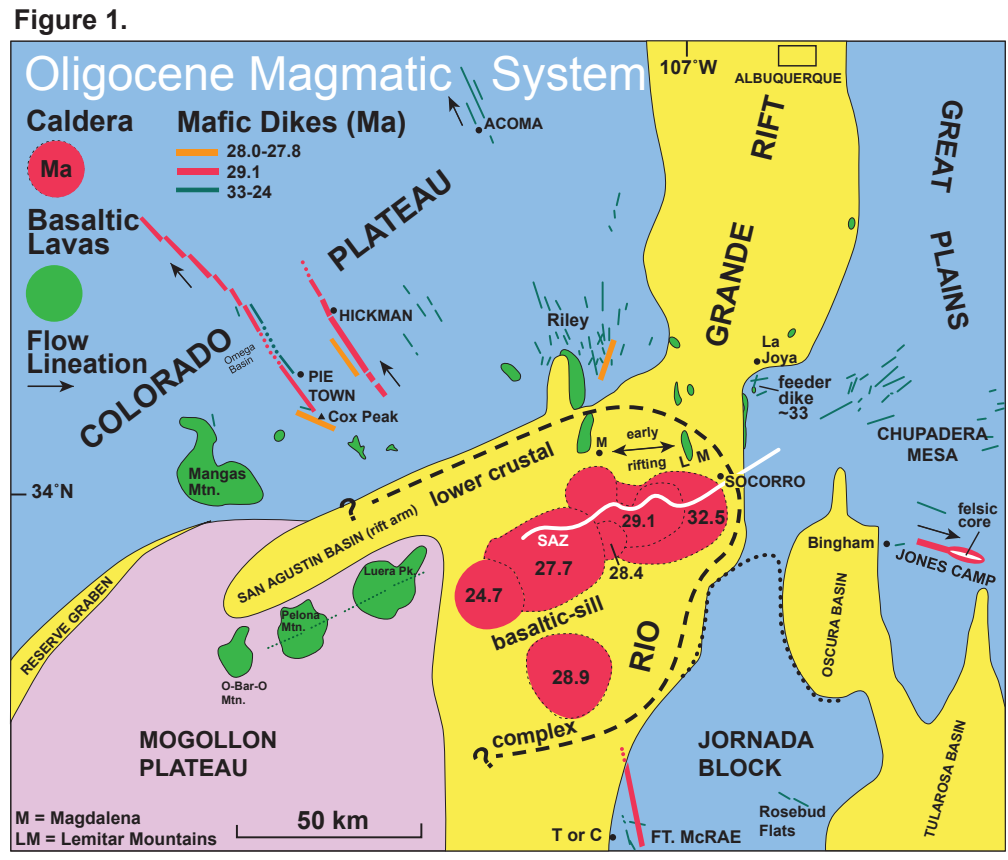

Figure 2.

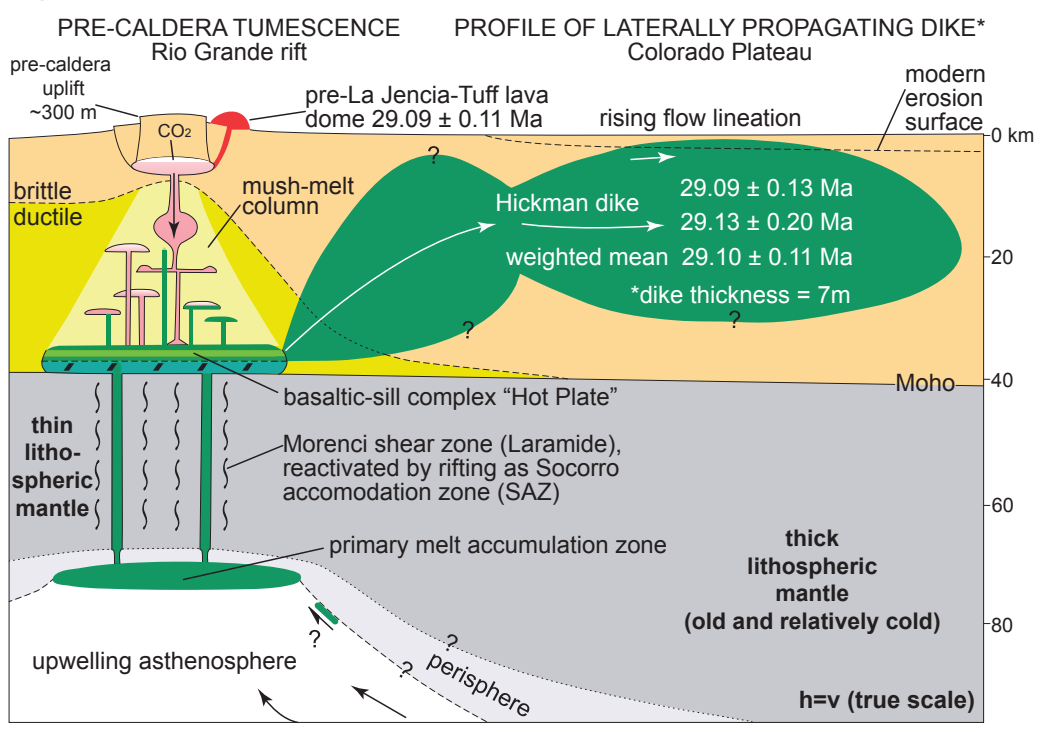
home.html 


\title{
Intrinsic conditions of magmas in Lunar Crater Volcanic Field, Nevada.
}

\author{
J.A. Cortés ${ }^{1}$, E.I. Smith ${ }^{2}$, Racheal Johnsen ${ }^{2}$, E. Widom ${ }^{3}$, G.A. Valentine ${ }^{1}$ \\ 1 Department of Geology, 411 Cooke Hall, Buffalo, NY 14260, State University of New York, USA. \\ 2 Department of Geoscience, 4505 S. Maryland Parkway, Las Vegas, NV 89154, University of Nevada, Las Vegas, USA. \\ 3 Department of Geology and Environmental Earth Science, 114 Shideler Hall, Oxford, OH 45056, Miami University, USA.
}

Geochemistry of the products of Quaternary monogenetic volcanoes in the northern part of the Lunar Crater volcanic field shows clear differences between spatially close and coeval volcanoes [1]. In this contribution we further constrain the intrinsic conditions of such magmas based on geothermobarometry performed using the mineral chemistry of phases occurring in the volcanic products. We have informally named the studied units OPB (older, phenocryst-bearing unit), PB (plagioclase bearing), YMB (younger, megacryst- and phenocryst-bearing unit) and Qml (Marcath volcano) [2]. Mineral phases in all of the studied products are olivine, clinopyroxene, plagioclase and a minor amount of groundmass titanomagnetite.. Olivine ranges between $\mathrm{Fo}_{88}$ and $\mathrm{Fo}_{60}$ in $\mathrm{PB} / \mathrm{OPB}$ and between $\mathrm{Fo}_{88}$ and $\mathrm{Fo}_{75}$ in $\mathrm{YMB} / \mathrm{Qml}$. A narrow range of diopsidic compositions occur in $\mathrm{PB} / \mathrm{OPB}$, while some high-Ca diopside is the common composition in $\mathrm{YMB} / \mathrm{Qml}$. Plagioclase is mostly bytownite with the occurrence of andesine and anorthoclase in PB and anorthite in OPB. Since no melt inclusions or groundmass glass occur in the samples, geothermometry was based on olivine-clinopyroxene mineral equilibria [3] while geobarometry and oxygen fugacity were based on clinopyroxene mineral chemistry [4,5]. Calculated temperatures for $\mathrm{PB} / \mathrm{OPB}$ are $\sim 1050^{\circ} \mathrm{C}$, between 950 and $1150^{\circ} \mathrm{C}$ for $\mathrm{YMB}$ and $\sim 1000^{\circ} \mathrm{C}$ for Qml. Calculated pressures for $\mathrm{PB} / \mathrm{OPB}$ are between 9 and $10 \mathrm{kbars}$, between 5 and $15 \mathrm{kbars}$ for $\mathrm{YMB}$ and between 3 and $15 \mathrm{kbars}$ for $\mathrm{Qml}$. In terms of intrinsic oxygen fugacity, $\mathrm{PB} / \mathrm{OPB}$ ranges between $\triangle \mathrm{QFM}+3$ and $\Delta \mathrm{QFM}+5, \mathrm{YMB}$ ranges between $\Delta \mathrm{QFM}$ and $\Delta \mathrm{QFM}+3$ while $\mathrm{Qml}$ ranges between $\Delta \mathrm{QFM}+2$ and $\Delta \mathrm{QFM}+4$. These results constrain the depth of a crystallising event between 12 and $60 \mathrm{~km}$, and suggest clear differences between plumbing systems for all the units. Results also suggest similar evolution for the younger units (YMB and $\mathrm{Qml}$ ) but a different history for the older, phenocryst bearing units. This conclusion is strongly consistent with our geochemical results [1].

[1] Widom et al., (2012) this volume

[2] Valentine et al., (2011) EOS Fall AGU fall V33C-2657

[3] Loucks (1996) Contrib. in Min. and Pet. 125: 140-150.

[4] Nimis (1999) Contrib. in Min. and Pet. 121: 115-125.

[5] Cortés et al., (2006) JPet 47(7): 1345-1373 
Into the cone: a ground penetrating radar study of cone-buiding processes at Cerro Negro volcano, Nicaragua

\section{Leah Courtland, Sarah Kruse, Chuck Connor}

Cinder cones, also called scoria or tephra cones, represent the most common type of volcanism on earth. These "toy" volcanoes are comprised of a combination of pyroclastic material and lava flows and pose a significant threat to life and property during times of eruptive activity. Though cinder cones have long been considered the simplest example of volcanism, models of their formation have advanced very little from their original formulation in the 1970s. Furthermore, while competing models can account for the geometry of observed deposits in a general sense, none address finer scale cone features such as asymmetries in the cone due to variable deposition mechanisms, the pervasion of granular flows vs. in-situ deposits, or the presence of faulting. In order to gain a better understanding of near vent processes which may be used in volcanic modeling and hazard assessment, new data collection techniques must be implemented. Ground penetrating radar imaging of tephra can reveal details of deposits at depths of approximately 2-20+ meters. Data collected in the September of 2007 and January of 2010 is here used to investigate the cone building processes of Cerro Negro, an active basaltic cinder cone in Northwestern Nicaragua. The data display evidence of cone steepening over time, patterns of ballistic and tephra dispersal, granular flows, and faulting within the cone, among other features.

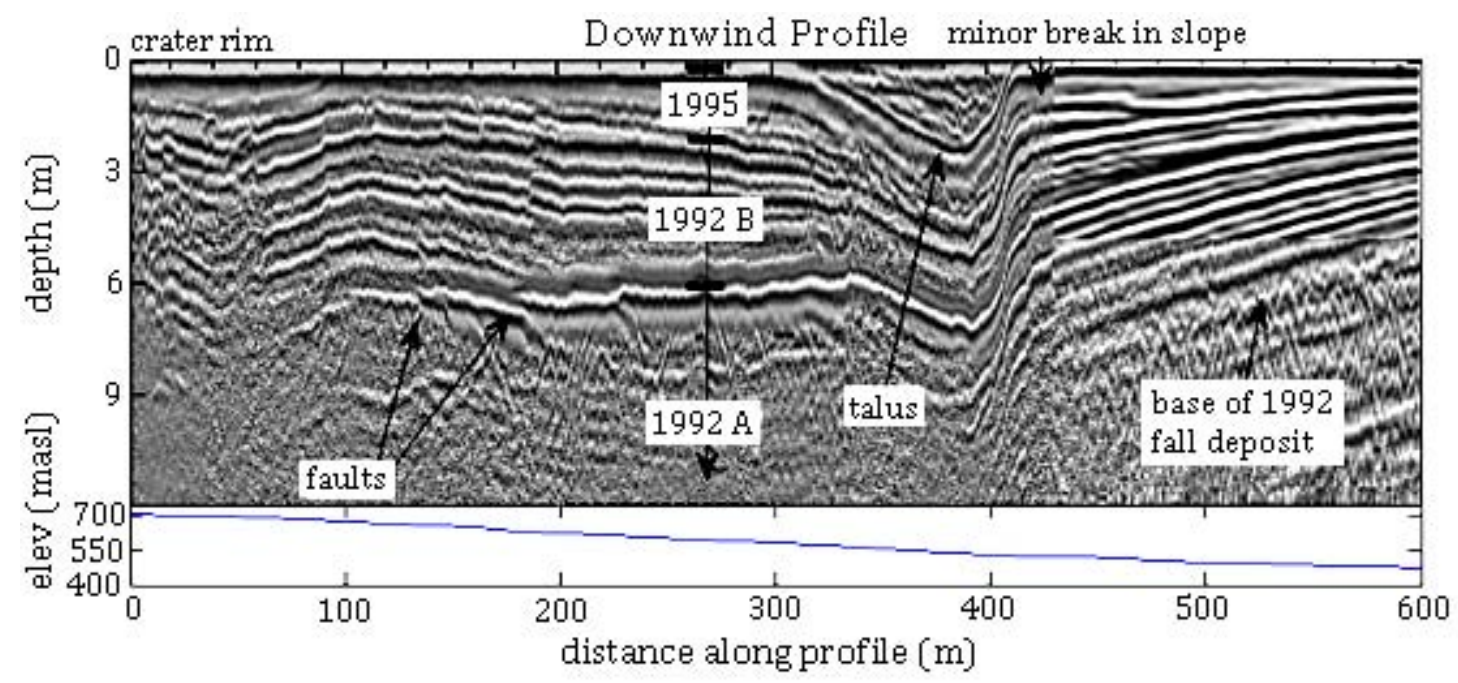

Figure: Ground penetrating radar profile crests crater rim and heads radially outward in the direction of maximum plume deposition. Up-cone profile collected with $100 \mathrm{MHz}$ antennas, farther down the cone data collected with both 50 and $200 \mathrm{MHz}$ antennas. Deposits from both the 1992 and 1995 eruptions are identified. 


\title{
Geochemistry and Hazard Assessment of Pliocene-Quaternary Volcanism Beneath the central Sierra Nevada and Adjacent Great Basin, northern California and Western Nevada
}

\author{
Brian Cousens, Ottawa-Carleton Geoscience Centre, Department of Earth Sciences, \\ Carleton University, Ottawa, ON. K1S5B6, Canada \\ Christopher D. Henry, Nevada Bureau of Mines and Geology, University of Nevada, \\ Reno., NV. 89557, USA.
}

\begin{abstract}
Latest Pliocene to Quaternary, mildly alkaline, primarily mafic volcanic activity extends in a swath from the Lake Tahoe region in the eastern Sierra Nevada across the western Great Basin to the Battle Mountain area, Nevada. This region overlies a zone of high heat flow and lithospheric thinning, termed the Humboldt Lineament, and is a zone of potential volcanic hazard. The Lake Tahoe region is a major locus of four-season tourism in the central Sierra Nevada (Smith et al., 2004). In 2003 and 2004, a series of deep $(\sim 30 \mathrm{~km})$ earthquakes occurred beneath the north shore of Lake Tahoe, where the progression of earthquake depths and the focal mechanisms are consistent with a magmatic dyke intrusive event. Youthful, explosive cinder cones are common in the Tahoe area. The area around Fallon, NV., the site of a major naval air station and a population of over 6,000 people, hosts two tuff cone and maar complexes that are less than 25,000 years old (Fultz et al., 1984). These volcanoes record explosive phases of volcanic activity that would have an impact on the nearby population.

The goal of our petrological and geochemical work is to determine the sources of volcanic activity, what processes dominate the magmatic evolution of the lavas, and how these processes impact the style of eruptive activity along the Tahoe to Battle Mountain swath of volcanic activity. From west to east, the volcanic centers exhibit a dramatic gradient in chemical and isotopic composition. Centers situated in or adjacent to the Sierra Nevada have incompatible element and isotopic compositions consistent with an old, subduction-modified lithospheric mantle source $\left({ }^{87} \mathrm{Sr} /{ }^{86} \mathrm{Sr}>0.7045 ; \delta^{18} \mathrm{O}>+6.5 \%\right.$ o $)$. Mafic volcanic centers east of the Sierra Nevada, in the Carson Sink and in the Buffalo Valley region, have an intraplate incompatible element and isotopic signature $\left({ }^{87} \mathrm{Sr} /{ }^{86} \mathrm{Sr}<\right.$ $0.7045 ; \delta^{18} \mathrm{O}<+6.5 \%$ o) consistent with an asthenospheric mantle source. Earlier $20-3$ Ma arc volcanism in the Sierra Nevada also tapped the old lithospheric mantle source along with the mantle wedge, indicating that the lithospheric mantle source existed well prior to the onset of Tertiary arc volcanism. Thus the lithospheric mantle beneath the Sierra Nevada has remained a geochemically consistent, fertile, fusible source for at least the past $20 \mathrm{Ma}$. Lithospheric mantle was also an important source for Miocene mafic through intermediate volcanic rocks erupted in the Fish Creek, Clan Alpine, Stillwater, Desatoya, Lahontan, and other ranges west and south of Battle Mountain, as a result of rollback of the Farallon plate beneath North America. Old lithospheric mantle likely still exists beneath the Great Basin east of the Sierra Nevada, but lithospheric thinning and/or exhaustion of fusible components inhibits its melting such that during the Quaternary melting could only occur in the asthenosphere. Young, explosive volcanic activity is associated with magmas derived from both types of mantle source.
\end{abstract}




\title{
ENVIRONMENTAL CONSEQUENCES OF LARGE VOLUME LAVA FLOW FIELDS IN THE SOUTHWEST: PRELIMINARY INFERENCES FROM MAPPING THE MCCARTYS LAVA FLOW FIELD, NEW MEXICO
}

\author{
L.S. CRUMPLER ${ }^{1}$, J.E. BLEACHER ${ }^{2}$, S. SELF ${ }^{3}$, J.R. ZIMBELMAN ${ }^{4}$, W. B. GARRY ${ }^{5}$, J. C. AUBELE ${ }^{1}$,
}

${ }^{1}$ New Mexico Museum of Natural History \& Science, 1801 Mountain Rd NW Albuquerque, NM, 87104,USA, larry.crumpler@state.nm.us, (2) Planetary Geodynamics Laboratory, NASA Goddard Space Flight Center, (3) Dept. of Earth and Environmental Sciences, The Open University, UK, (4) Smithsonian Institution, National Air and Space Museum, (5) Planetary Science Institute, Tucson, AZ

Introduction. Conditions necessary for eruption of two large, several cubic kilometer basaltic lava flows (each 3 to 6 $\mathrm{km}^{3}$ ) have prevailed in last 5,000 yrs in New Mexico (McCartys and Carrizozo). Although lava eruptions of this scale are relatively infrequent, a basaltic eruption of a similar volume (Laki, [1]) was one of the most globally disruptive volcanic events in recorded history due in part to the sulfur and halogen aersols and the relatively widespread effects on the environment at the time, including global cooling. Because of the potential for profound influence on society, both in the Southwest and globally, and because the geologic conditions necessary for a repeated occurrence may still persist, the special environmental effects of a repeated event of this scale should be assessed.

This study was initiated in part to document the mechanisms and rates of emplacement of the McCartys lava flow field through mapping of physical surface units and acquisition of high resolution relief data. The findings are proving useful on several fronts. They are enabling development a more complete picture of the substantial role of inflation in development of large lava flow fields, provide a more detailed picture of the volume, effusion rates, and timing of the eruption, and provide a modern proxy for details of flood basalt emplacment. These results in turn provide some constraint on likely patterns of sulfur and halogen release and aerosol production, and the corresponding environmental consequences that may have prevailed at the time of the eruption ( 3.2 ka before present, [5]).

Volume. The McCartys lava flow field covers approximately $220 \mathrm{~km}^{2}$ and extends $52 \mathrm{~km}$ from south to north, the flows reaching a maximum distance of some $40 \mathrm{~km}$ from the small vent region located in the southern half of the flow. Our current estimates of volume lie between 3 and $6 \mathrm{~km}^{3}$ (the volume of the Laki eruption is $14 \mathrm{~km}^{3}$ ). The surface of the lava flow preserves glassy crusts, is dominantly pahohoe, and evidence for inflation of the surface is prevalent.

Mapping. A pilot mapping effort was initiated to unravel the details of the lava emplacement, focusing on the spatial and temporal patterns of sheet lobe emplacement and the evidence of eruption longevity from patterns of inflation. One of goals is to understand the net volume and overall timing of the released volatiles and pyroclastic materials. Thicknesses of disrupted surface slabs, evidence for crustal thicknesses at the time of deformation on plateau margins, and mapped distribution and timing of subsequent multi-generation flow lobes provide estimates of duration of the eruption. We can account for approximately two years within the detailed map area and later we hope to have an estimate for the duration of the entire eruption sequence.

Volatile effects. As an example of the impact of volatiles released during the eruption, consider possible $\mathrm{SO}_{2}$ production. We have yet to measure the $\mathrm{S}$ contents of glassy rinds, but assuming that the relationship between composition (specifically $\mathrm{TiO}_{2} / \mathrm{FeO}$ ) and $\mathrm{S}$ concentrations are similar to those in recent tholeiitic eruptions [2], values of $1000-1500 \mathrm{ppm}$ $\mathrm{S}$ are reasonable. Ignoring details of the distribution (magma, pyroclastics, and included phenocrsts) in the light of the prelimnary nature of the volume estimates, and using estimates of S emissions from [3], the McCartys eruption could have yielded 20 to $30 \mathrm{Tg}$ of $\mathrm{SO}_{2}$ within the space of a few years. This is equivalent to the largest historic explosive eruptions for which $\mathrm{SO}_{2}$ impact on the atmosphere was notable. Given our initial estimates of eruption duration, the rates of $\mathrm{SO}_{2}$ release were likely on the order of $1 \mathrm{Tg}$ per month. This is 30 to 100 times the production of large copper smelters [4]. Lessor basaltic eruption could yield disruptive gas release, although in quantities that scale with their erupted volume. References: [1] T. Thordarson, S. Self, Bull. Volcanol. 55 (1993) 233-263; [2] T. Thordarson, S. Self, J.D. Miller, G. Larsen, E.G. Vilmundar-dottir, Volcanic Degassing, Geol SocLondon Special Pub, vol. 213, 2003, pp. 103-122.; [3] Self et al. 1991. EPSL, 248 (2006) 518-532. [4] Carn eta; 2007. GRL, 34, L09801 doi:10.1029/2006GL029020. [5] Dunbar, and Phillips, 1994 New Mexico Geology, v. 16, no. 4, p. 80.

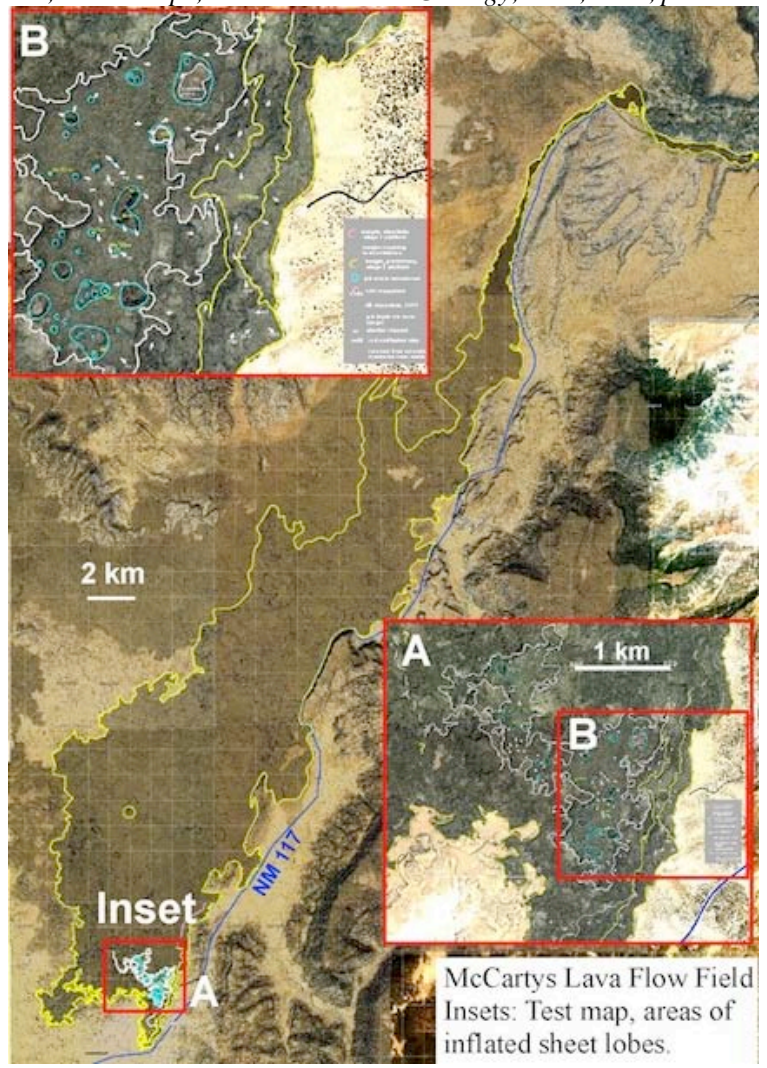


THE NEW MEXICO VOLCANO COLLECTION AND RESOURCE: VOLCANOES OF NEW MEXICO WEBSITE DEVELOPED BY THE NEW MEXICO MUSEUM OF NATURAL HISTORY \& SCIENCE L.S. Crumpler ${ }^{1}$, J.C. Aubele ${ }^{1}$, R. Elsinger ${ }^{1}$, and M.Celeskey ${ }^{1}$

${ }^{1}$ New Mexico Museum of Natural History and Science (1801 Mountain Rd. NW, Albuquerque, NM, 87104, jayne.aubele@state.nm.us)

A Collection of Volcanoes: The New Mexico Museum of Natural History and Science is developing an updated resource for all geoscientists and the public that will provide current information, maps, and images for volcanic areas and individual volcanoes, within the state of New Mexico. Although most Museum collections consist of physical objects that can be housed within the walls of a building, volcanoes present a problem. Volcanic rock types can be collected, but the entire state of New Mexico is a "museum" of all of the various types of volcanological edifices and eruptive styles, and these cannot be physically collected. They can, however, be collected as photographic images, maps, and detailed information; and this collection will be useful to both the general public and the research volcanologist. That is the intent of the "Volcanoes of New Mexico" website.

The website opens with a map of the state with all volcanic fields and regions of volcanism shown. A click on any one of these areas sends the viewer to more detailed maps, photographs, and information about the area. Layers of information are given so that the interested non-scientist can read a basic summary, while the research volcanologist can access the most recently published research. Compiling and updating this information is being done by a team consisting of the Museum's Curator of Volcanology (Crumpler), Geoscience Educator (Aubele), Graphic artist (Celeskey), and committed volunteers, including Museum volunteers and classroom teachers. The updated Volcanoes of New Mexico website will be linked to the Museum website

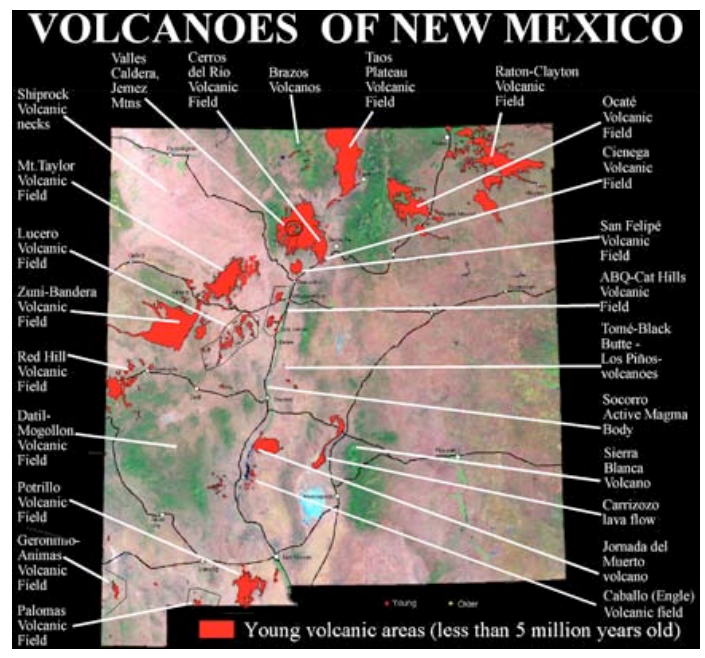

(www.NMnaturalhistory.org) for easy access. Increasing regional volcano literacy: Geology is frequently perceived by the student, teacher, or adult non-geologist as "difficult to understand"; however, most non-geologists of all ages notice and appreciate scenic or exciting landforms such as volcanoes and are interested in related phenomena such as earthquakes and the development of mineral resources. The New Mexico Volcano Collection and Resource, as part of the Museum's website, is an opportunity to increase the non-geologist's understanding of New Mexico's volcanoes and to excite the general public about volcanological research.

The Museum Advantage: Museums, as informal science education centers, have the following advantages in volcano-related education for the public: (1) graphics/display expertise; (2) flexibility in approach and programming; (3) self-directed learning opportunities; (4) audience ranging from pre-K through Senior Citizen; and (5) accessible, visitor-friendly and non-threatening resource site. The general public is interested in the local and regional geology and is fascinated by volcanoes; however, most people don't know how or where to obtain this information. Museums and museum websites are trusted resources for concise, factual, reliable and entertaining presentations of the relevant information. By emphasizing the local or regional connection, museums allow people to make a personal connection to scientific research and new discoveries in their own "backyards." K-12 teachers are able to make use of Museum programs, content, and the ongoing research that also takes place in Museums to provide a "real world" approach to science in the classroom.

In addition, museums serve a wide audience, For example, the New Mexico Museum of Natural History and Science is a statewide institution, part of the New Mexico Department of Cultural Affairs. It serves a regional population that includes $38 \%$ Hispanic and 9\% Native American, as well as a high percentage of rural communities, and therefore reaches an audience traditionally underrepresented in science. With the increase in web-based information and learning, the Museum website is perfectly placed to become an important resource for a statewide, national, and global population interested in volcanoes. 


\section{Volcano Work Groups and Effective Communication Partnerships for Volcanic Hazards Education Carolyn L. Driedger driedger@usgs.gov tel: 360-993-8907 USGS-Cascades Volcano Observatory, 1300 SE Cardinal Court, Vancouver, WA, 98683}

In Washington and Oregon, public officials, emergency managers, first responders, park staff, and emergency educators, and scientists participate in regional volcano hazard work groups that plan responses to volcanic activity within their jurisdictions. Work group agencies are trained to exercise the response and recovery plans effectively, enabling them to communicate with the public about regional volcano hazards. That communication can be most influential when multiple sectors within the community work as a team to deliver consistent and complementary messages. Each sector has a specific intention and function: emergency managers and public officials require up-to-date and exercised coordination plans and an informed and supportive community; educators endeavor to create a more informed younger generation; community and tourism officials plus, park interpreters and managers wish to provide up-to-date and meaningful interpretation, and resource management; scientists strive to provide accurate information, technically sound interpretations, and useful hazards assessments; the media seeks an interesting story. All seek to raise awareness and preparedness. The effort shows successes that are measurable in part by surveys of community awareness and preparedness. Partnerships provide potential for consistent and efficient dispersal of information that can lead to improved awareness, safety policies, heightened protection, and increased appreciation of volcanic parks and preserves. Consider these guidelines when initiating a volcano outreach plan in your community:

- Determine desired outcomes, such as governmental policy improvements and funding support for volcano monitoring, mitigation plans by emergency responders, and measureable heightened awareness and personal preparedness by officials and populations at risk.

- With partners, craft consistent and complementary key messages that explain hazards, and the importance of intra-community risk mitigation and personal preparedness measures, stressing how these actions will bring family and personal safety, peace of mind, and greater appreciation of nearby Cascade volcanoes.

- Seek partnerships with policy makers, professional information disseminators and vested interest groups who can be advocates-emergency managers, educators, health practitioners, community and business leaders, park interpreters, media, and other groups with interest in general preparedness. Confer less attention on the diffuse "general public" and more focus on established social groups that can re-transmit key messages with efficiency.

- Develop outreach products and services in partnership, usable by and for local communities.

- Measure effectiveness. Plan pre- and post-outreach assessments of community knowledge.

- Extend your reach. Use multiple approaches to establish your message. Plan for a long-term yet sustainable commitment. Show how cooperation leads to family protection, peace-of-mind, community economic benefits, and faster recovery after disaster.

Communication partnerships can increase the impact and sustainability of volcano hazards and mitigation, even when resources are limited. 
Volcanism in New Mexico: Past activity and future expectations: Zuni-Bandera Volcanic Field, Valles Caldera, Socorro magma body, and beyond.

Nelia W. Dunbar, William C. McIntosh. New Mexico Bureau of Geology and Mineral Resources, New Mexico Tech, Socorro, NM, 87801. nelia@nmt.edu;

mcintosh@nmt.edu

Volcanism has been widespread throughout New Mexico over the past $\sim 2 \mathrm{Ma}$, with two main compositions, basaltic and rhyolitic, represented. The basaltic volcanism occurs mainly along the Rio Grande rift or the Jemez lineament, and occurs in nine distinct fields (Figs 1 and 2). The rhyolitic volcanism is focused in the Jemez Mountain volcanic center, which is located at the intersection of the Rio Grande rift and the Jemez lineament, and features two, large-volume, highly explosive eruptions, the deposits of which are widespread throughout the state. A compilation of the ages and geographic distribution of New Mexico Quaternary volcanism suggests no systematic episodicity or variation in geographic location of eruptions, but rather a consistent level of temporally and geographically distributed activity. In terms of geographic distribution, much of the volcanism that has occurred over the past $\sim 2$ Ma has been basaltic, with rhyolitic activity occurring only in the Jemez Mountain Volcanic Field. Based on that observation, the next recurrence of volcanism in New Mexico would be most likely to be basaltic, although rhyolitic activity cannot be ruled out.

Furthermore, the style of volcanism will most likely be a small lava flow with associated cinder cone. This style of anticipated activity will probably have

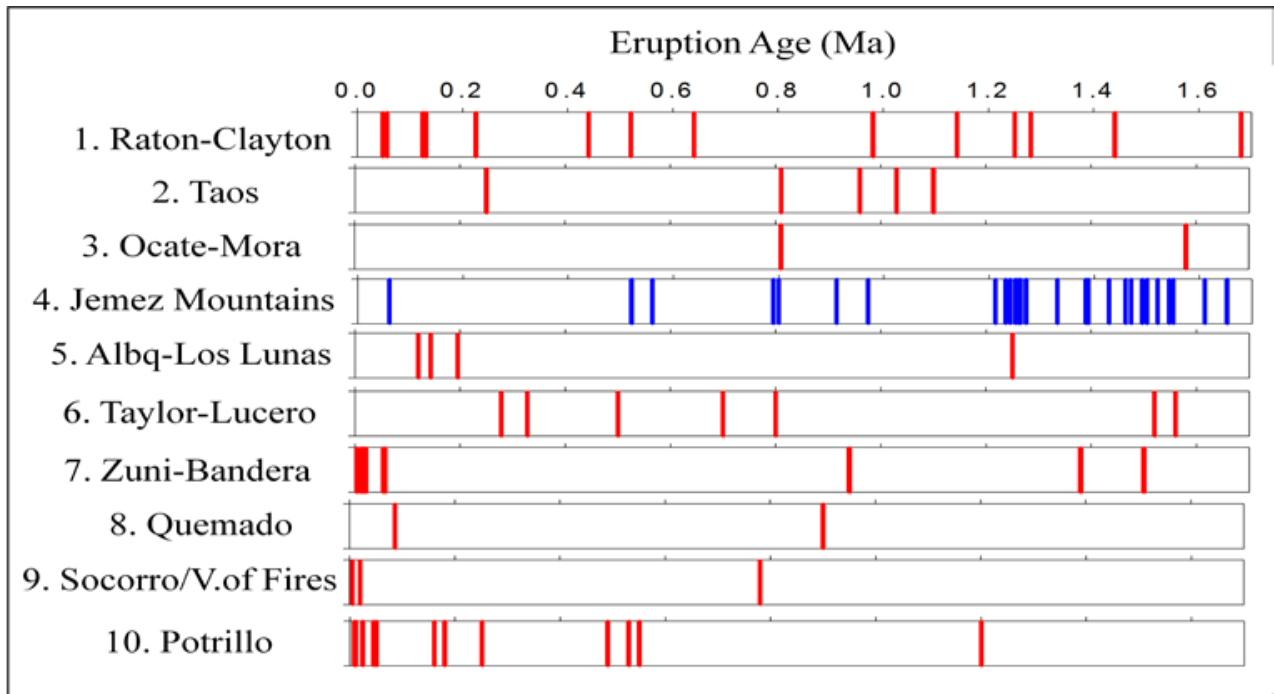

Figure 2. Integrated ages of $<1.7 \mathrm{Ma}$ volcanism in New Mexico. Red lines indicate basaltic activity, blue lines rhyolitic, which occurs only in the Jemez Mountain Volcanic Field.

little impact on the local climate, although impact on landscape evolution, particularly through disruption of drainage patterns, could be significant. Based on the frequency of eruptions over the past 5 $\mathrm{Ma}$, there is a 1\% chance of a volcanic event in New Mexico in the next 100 years (Limburg, 1990), and the most likely location of activity will be associated with the geophysically-defined Socorro magma body. This tabular magma body, the top of which is located at $19 \mathrm{~km}$ depth in the central part of the state (Fig. 2), has been recognized for many years through geophysical observations (see Aster et al., this volume). More recently, anomalous seismicity, crustal deformation measured at $\sim 2.5 \mathrm{~mm} / \mathrm{yr}$ and long-term heat flow have been recognized associated with this sill-like magma body. Most discussion of this magma body in the literature suggests that it is probably basaltic, but the possibility that it contains rhyolitic magma cannot be ruled out. 


\title{
Human Adaptation to Catastrophic Events: Lessons from the $11^{\text {th }}$ Century CE Eruption of Sunset Crater Volcano
}

\author{
Mark D. Elson, Desert Archaeology, Inc. \\ Michael H. Ort, Northern Arizona University
}

The Flagstaff area was never an easy place to make a living. Situated in an area early Spanish explorers aptly named "Sierra Sin Agua" (the mountains without water), the climate and topography of the region are barely sufficient for long-term settlement. Water sources are rare and permanently flowing streams almost nonexistent. The climate is harsh and unpredictable, with only areas above $1,900 \mathrm{~m}$ in elevation receiving sufficient precipitation for corn cultivation. The >600 cinder cones in the San Francisco volcanic field covered the ground surface with thick layers of black basalt tephra and rendered large areas barren of vegetation and inhospitable to settlement.

Sunset Crater Volcano is located $\sim 20 \mathrm{~km}$ north of Flagstaff. New data from the archaeological excavation of 40 prehistoric sites in the Sunset Crater area, combined with geochemical and dendrochemical analyses, suggest that the volcano erupted for a short period (weeks to months) sometime between 1060 and $1090 \mathrm{CE}$, and most likely around $1085 \mathrm{CE}$. At the time of the eruption, nearby areas were densely populated by small, prehistoric farming groups that archaeologists call the Sinagua. Lava and tephra were deposited over an area of $2,300 \mathrm{~km}^{2}$, dramatically changing both the physical landscape and the world view of the prehistoric inhabitants.

Agricultural experiments demonstrate that an area of greater than $400 \mathrm{~km}^{2}$ had to be abandoned due to the deposition of a scoria cover deeper than 20-30 cm, under which agriculture was no longer possible, and roof collapse likely occurred in a much larger area. Given the density of pre-eruptive settlement in this area, 1000s of volcano refugees were likely displaced. Conversely, these same agricultural experiments agree with earlier research showing that the deposition of a 3-8-cm-thick layer of scoria acted as a mulch and increased moisture retention enough to support agriculture in areas previously too dry to be farmed.

Prehistoric populations not only adapted to these conditions, they thrived. The archaeological evidence strongly suggests that within a few years following the eruption, many of the volcano refugees migrated $15-20 \mathrm{~km}$ north of Sunset Crater into the arid lower elevations that were now covered by $3-10 \mathrm{~cm}$ of tephra. Here they developed new technological methods to manage the tephra mulch and ensure agricultural success in an area receiving less than $200 \mathrm{~mm}$ of yearly precipitation. This previously little inhabited area - now called Wupatki National Monument - soon became the site of some of the largest pueblo structures ever built in the Flagstaff area.

The deliberate creation of corn-impressed pieces of lava further suggests that the local inhabitants made ritual offerings to the volcano, which likely played a role in their successful adaptation. Studies of catastrophic events show that religious mechanisms for coping with a natural disaster are highly adaptive, enabling affected individuals and groups to more readily accept the event and begin the recovery process. The results of these investigations are used to examine human adaptation to catastrophic events in general. Today, more than 900 years after Sunset Crater arose on the landscape, the Hopi, who are thought to be the descendents of the prehistoric Sinagua, still pass accounts of the eruption from generation to generation as a part of traditional clan knowledge, underscoring the significance of this event. 


\section{ERUPTION POTENTIAL AND HAZARD, VALLES CALDERA, NEW MEXICO}

Fraser Goff, Earth and Planetary Sciences Department, University of New Mexico, Albuquerque, NM 87131, candf@swcp.com

The 22-km-diameter Valles caldera (1.25 Ma) is famous as the type locality of large resurgent calderas, the host of a classic $260-300{ }^{\circ} \mathrm{C}$ liquid-dominated geothermal system, the site of a seminal investigation identifying the Jaramillo and Santa Rosa paleomagnetic events, and the location of a large 552-368 ka mid-Pleistocene lake. Valles formed during eruption of ca. $400 \mathrm{~km}^{3}$ of Tshirege Member, Bandelier Tuff and is the only large Quaternary caldera in the southwestern USA. After caldera formation, a short period of resurgence and associated rhyolitic volcanism (1.25 to $1.22 \mathrm{Ma}$ ) was followed by major ring fracture volcanism from 1.22 Ma to $40 \mathrm{ka}$. About 25 rhyolite domes, flows and minor tuffs were erupted from the ring fracture zone. Thus, on a very crude statistical basis, the ring fracture has produced about 1 eruption every $50 \mathrm{kyr}$ since caldera formation.

Various geologic, geochemical and geophysical investigations conducted during the last 35 years provide additional insight on eruption potential and hazard. Hydrothermal activity once occurred throughout most of the caldera, but the present geothermal system is centered in the SW sector of the resurgent dome and ring fracture zone, nearly coincident with the youngest rhyolitic eruptions. ${ }^{3} \mathrm{He} /{ }^{4} \mathrm{He}$ ratios of the hydrothermal fluids range from 4.5 to $6 \mathrm{R} / \mathrm{R}_{\mathrm{A}}$ indicating a significant contribution of primordial helium and a current pathway from the mantle. Seismic investigations show that a circular low-velocity zone extends to the mantle beneath the SW caldera. Modeling indicates a melt fraction of 10 to $30 \%$ at 5 to $15 \mathrm{~km}$ depth. In contrast, limited geodetic and GPS surveys show that the resurgent dome is static and that the caldera is relatively aseismic compared to adjacent fault systems such as the Rio Grande rift.

Although another caldera-forming eruption of Bandelier Tuff scale is highly unlikely, the youngest group of Valles eruptions (East Fork Member) exhibits explosive character and may provide an example for future eruptions. This group consists of the El Cajete Pyroclastic Beds and Battleship Rock Ignimbrite $\left(55 \mathrm{ka}, \geq 10 \mathrm{~km}^{3}\right)$ followed by the Banco Bonito Flow $\left(40 \mathrm{ka}, \sim 4 \mathrm{~km}^{3}\right)$. These units are chemically and mineralogically distinct from ring-fracture rhyolites that erupted $460 \mathrm{kyr}$ earlier and may record onset of a new magmatic cycle at Valles. Plinian eruptions from the El Cajete event were dispersed mostly to the south and east covering much of eastern New Mexico in ash. Due to rugged topography, ignimbrites and flows were restricted to the immediate Valles caldera area.

In summary, a magma chamber resides beneath the southwestern Valles caldera, which provides heat and volatiles to an active geothermal system. Although future rhyolitic eruptions at Valles are possible, it is presently impossible to predict when these will occur. Eruption products and volumes produced by the young East Fork Member suggest that rhyolitic plinian eruptions are probable and most likely to effect surrounding regions. 


\section{Estimating remobilization rate of ash deposited during the Puyehue (Southern Andes) eruption in 2011}

Miguel J. Haller, Universidad Nacional de la Patagonia San Juan Bosco \& CONICET (haller@cenpat.edu.ar) Oscar A. Frumento, Centro Nacional Patagónico - CONICET (oscar@ cenpat.edu.ar)

Puyehue - Cordón del Caule volcano in Southern Andes erupted explosively in June 2011 depositing ash over a region of more than $75,000 \mathrm{~km}^{2}$ to the east and southeast of the volcano in the Argentine Patagonian meseta. A minimum of $1.36 \mathrm{~km}^{3}$ of uncompacted tephra was ejected, which is equivalent to $0.29 \mathrm{~km}^{3}$ of solid rock. The thickness of ash ranged from $30 \mathrm{~cm}$ in the Andean area to less than $1 \mathrm{~mm}$ in the Atlantic coast zone. This deposited ash has been frequently remobilized for months by the wind impacting on the population, transportation, agriculture, livestock and water resources of the region.

The research was carried out to determine whether it would be possible to predict the time required for the complete remobilization of ash and its related effects. In order to estimate the transport of volcanic dust deposited over an extended area of the argentine northern Patagonia the coupled dust-RegCM4 regional climate model has been used over an area covering southernmost South America. An imposed dust source area was deducted from satellite images of the first few days following the eruption. Particle distribution based on textural analysis of ash collected in the Meseta Central was further associated to the four categories of particles sizes (from $0.1 \mu \mathrm{m}$ to $20 \mu \mathrm{m}$ ) the coupled dust-REGCM4 usually handles.

Modelling approach based on empirical field observations, considers that one third of the fallen ash is fixed by the vegetation or incorporated into the soil by illuviation processes, while two thirds are resuspended by the wind. The climate model allowed us to calculate a monthly average emission rate (catch and remobilization of particles outside the region) $700 \mathrm{~g} / \mathrm{m}^{2}$, equivalent to $52 \times 10^{6}$ tons $/$ month. Based on these calculations it was estimated that the remobilization of Puyehue volcano ashes and decreasing of the consequent adverse effects would extend for a period of 33 months. Current observations (July 2012) show that during strong wind storms volcanic ash reaches the Atlantic coast. 


\title{
Potential Contributions of Geodesy to Monitoring Volcanic Unrest in the Southwest United States
}

\author{
William C. Hammond, Corné Kreemer, Geoffrey Blewitt \\ Volcanism in the American Southwest, October 18-20, 2012 \\ Flagstaff, AZ
}

\begin{abstract}
Precise and timely measurement of surface deformation associated with volcanic or tectonic unrest is a highly valuable component of a coordinated response to precursory activity such as seismic swarms. Geodesy, in combination with other geophysical datasets, has a role in each stage of the event information life cycle, including detection, characterization, integration and interpretation of data needed to provide understanding and warning of natural volcanism. Geodesy is particularly illuminating when surface deformation indicates that a large or even dominant fraction of the deformation is aseismic, as is the case for many intrusive events.
\end{abstract}

The geologic record of volcanism in the southwest US includes many young low-volume eruptions whose geographic distribution is strikingly similar to the contemporary zones of higher active crustal strain rate. Our recent experience with seismic swarms in the western Great Basin also suggests that magmatism is an active and possibly pervasive component of tectonic evolution the crust and upper mantle, and not only focused on existing large volcanic centers. Examples of recent swarms in eastern California and western Nevada include the 2003 Slide Mountain, 2008 Mogul/Reno, 2011 Hawthorne, and 2011 Sierraville episodes for which detailed seismic and geodetic datasets were collected. In each of these cases it was unclear early on how far the events would progress. While each had large numbers of earthquakes, their geodetically observed surface deformation characteristics varied substantially, as did the amount of verifiable contribution from a magmatic source. However, they were similar in their consistency with the dextral transtensional regime of western Great Basin and Walker Lane active tectonic deformation, further suggesting that maps of active crustal strain rate provide important information about volcanic hazards.

GPS networks that may contribute to monitoring future volcanic unrest include the NSF EarthScope Plate Boundary Observatory and the University of Nevada's flexible Mobile Array of GPS for Nevada Transtension (MAGNET). We will present results from a few recent case studies where MAGNET was deployed in response to seismic swarms. These cases illustrate the utility of GPS measurements, their precision, scope, and latency. We will describe the status of UNR's new low-latency, high rate data products that are now available or on the horizon, and also recent directions of a nascent communitywide surge in real time GPS data availability whose aim is to provide easier access to solutions with $\mathrm{cm}$ accuracy with latency near 1 second.

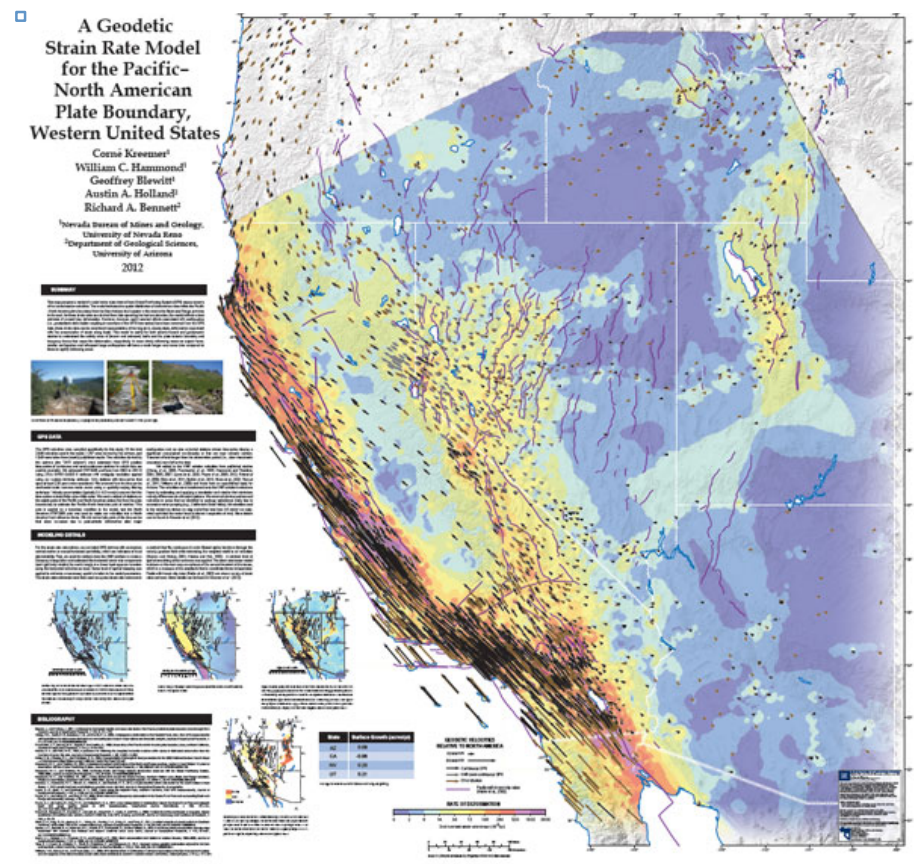

Figure (right). A geodetic strain rate map for a portion of the southwest U.S. For more information and free download see http://geodesy.unr.edu 


\title{
Young Volcanism of the Lake Tahoe - Reno - Fallon Area, California and Nevada: The Geologic Record
}

\author{
Christopher D. Henry, Nevada Bureau of Mines and Geology, University of Nevada, Reno, NV \\ 89557, USA \\ Brian Cousens, Ottawa-Carleton Geoscience Centre, Department of Earth Sciences, Carleton \\ University, Ottawa, ON. K1S5B6, Canada
}

\begin{abstract}
An approximately west-east belt of young volcanic rocks (mostly $\sim 2.6$ to $1 \mathrm{Ma}$, but at least as young as 10,000 years) extends $\sim 150 \mathrm{~km}$ from the north end of Lake Tahoe, California, through Reno to Fallon, Nevada. Additionally, two groups of deep earthquake swarms in the last ten years, one beneath the north end of the lake and another $\sim 50 \mathrm{~km}$ to the north-northwest, that are interpreted to indicate upward propagating igneous dikes suggest some potential for future volcanism (Smith et al., 2004). The belt of young volcanic rocks encompasses several population centers, a major transportation corridor, Lake Tahoe, and the Fallon Naval Air Station so assessment of potential volcanic hazard is worthwhile.

The young volcanic rocks are mostly basaltic but include a cluster of rhyolite lava domes. Volcanic eruptions in the north Tahoe area are as young as $0.9 \mathrm{Ma}$ (Kortemeier et al. 2009), were almost all basaltic, and formed numerous cinder cones and lava flows and at least one tuff cone, a more explosive type of eruption. These rocks form a semi-continuous belt eastward to Reno and Carson City, where several more cinder cones formed at $\sim 1.4 \mathrm{Ma}$ and were accompanied by at least three lava flows. Two lavas from one cone flowed $\sim 6 \mathrm{~km}$ into what are now suburbs of Carson City and across US Highway 50. Another lava flowed about $17 \mathrm{~km}$ down a canyon to the present I-80 and Truckee River, which it blocked at the time. Four rhyolite lava domes up to $\sim 600 \mathrm{~m}$ in diameter formed during mixed explosive-effusive eruptions at $\sim 1.2 \mathrm{Ma}$ in what are now the south suburbs of Reno. An $\sim 50 \mathrm{~km}$ wide gap of no known young volcanic rocks separates the Tahoe - Reno area rocks from those near Fallon, which are exclusively basaltic. The youngest and some of the most explosive activity in the region formed the Soda Lakes complex of several, partly overlapping maars individually up to $1.2 \mathrm{~km}$ in diameter and extending over a $2.5 \mathrm{~km}$ long, north-northeast zone northwest of Fallon. The maars cut Lake Lahontan sediments so are younger than $\sim 10,000$ years, possibly as young as 1,500 years. The Upsal Hogback group of overlapping maars, individually up to $1 \mathrm{~km}$ in diameter and extending over a $5 \mathrm{~km}$ long north-northeast zone that approximately aligns with Soda Lakes were extensively eroded by Lake Lahontan. They are probably $\sim 25,000$ years old based on the presence of basaltic tephra interbedded with sediments that are estimated to be that old. The north-northeast alignment of volcanic centers suggests control of magma transport through the upper crust by faults and fractures related to regional extension. An $\sim 1$ Ma cone and flow complex sits at the northeastern edge of Fallon. Another group of cinder cones and lava flows as young as $1 \mathrm{Ma}$ occurs in an unpopulated area south of Battle Mountain, Nevada about $150 \mathrm{~km}$ northeast of Soda Lakes and Upsal Hogback.

Most volcanism appears to have ended throughout the eastern California - western Nevada region at $\sim 1 \mathrm{Ma}$. The two maar complexes near Fallon are the only known Holocene or Late Pleistocene eruptions. However, they and the propagating dikes shown from seismicity allow the possibility of future eruptions. Given the record of activity over the last $2.6 \mathrm{Ma}$, future eruptions are likely to be basaltic. If emplaced into major groundwater basins, they could be highly explosive like the young maars. If emplaced into Sierra Nevada bedrock, eruptions probably would be less explosive, probably cinder cones accompanied by lava flows. We can offer no probability for an eruption but hope that any eruption would be long presaged by seismicity.
\end{abstract}




\section{Tephra dispersal and deposition from the Marcath eruption, Lunar Crater Volcanic Field, Nevada}

Peter Johnson, Greg Valentine, Marcus Bursik

Department of Geology, 411 Cooke Hall, University at Buffalo, Buffalo, NY 14260

email: peterjoh@buffalo.edu

Explosive volcanic eruptions pose well-established hazards to aviation and public health. One possible source for explosive eruptions is basaltic monogenetic scoria cones. Although generally regarded as a well-understood eruptive style, few data have been collected of tephra deposits from prehistoric scoria cone eruptions. This project focused on a 38 ka eruption at Lunar Crater Volcanic Field, NV, which produced a tephra fall deposit that can be traced up to $6 \mathrm{~km}$ from the source vent. A total of 28 sample sites were characterized for depth, maximum grain size, and scoria texture. Samples were collected at each site for laboratory determination of deposit density and, based on that, mass per area, as well as for granulometric analysis. Field data indicate that the deposit contains two beds which were likely produced by two separate phases of the eruption. We focused on the topmost bed due to its greater lateral extent, and the consequent interpretation that it resulted from a higher plume. Reconstruction of the eruption column based on mass per unit area is presently being undertaken to ascertain plume height and wind speed, but preliminary results based on grain size suggest an eruption column between 6 and $8 \mathrm{~km}$ in elevation with a $25 \mathrm{~m} / \mathrm{s}$ wind blowing to the northeast. Post-eruptive erosion has rendered identification of deposit boundaries difficult, resulting in a high degree of uncertainty in eruption column height. 
Focusing of melt by magma chambers in time and space: theory and application to Mount Mazama, Crater Lake, Oregon

Leif Karlstrom

Stanford

Heather M.N. Wright

USGS

Charles R. Bacon

USGS

Even during periods of constant melt flux into the crust, volcanic eruptions will be episodic in space and time. The crustal magma transport processes responsible for this unsteadiness are not available for direct observation. However, the distribution of vents and eruptive products at a given volcanic center provide important clues to the nature and time variation in magmatic plumbing. Many evolved centers exhibit a wide region of monogenetic vents surrounding a central composite volcano, with episodicity in the timing, composition, and volume of eruptions as functions of distance from the center.

Melt focusing (lensing) by magma chambers is one potential mechanism for generating spatio-temporal patterns in central vents versus monogenetic regional volcanism. Magma chambers that attain some overpressure with respect to the lithostatic stress gradient may affect the trajectory of rising melt, becoming effectively "lenses" for dikes rising from depth (Karlstrom et al., 2009). This is a mechanism for generating discrete volcanic edifices over a larger source region. The degree of lensing also varies in time, due to a positive feedback between overpressure and melt-focusing efficiency that creates a growing region of melt capture at depth. Lensing experiences a sudden decrease following centralized eruptions that drain the reservoir and relieve overpressure. This model thus predicts oscillating patterns of monogenetic regional volcanism and central vent eruptions.

We test predictions of the magmatic lensing model with data from Mount Mazama in the Oregon Cascades that document central vent eruptions and regional monogenetic volcanism over the past 400 ka (Bacon and Lanphere 2006, Bacon 2008). There are significant patterns in the volume, melt composition (silica content), and spatio-temporal occurrence of eruptions that are generically consistent with episodic focusing of rising melt by the Mazama magma storage zone. These patterns may reflect unsteady melt supply into the Mazama system, and a gradual increase in crustal modulation of rising melt, culminating in the climatic caldera-forming eruption that formed Crater Lake caldera at $\sim 7.7 \mathrm{ka}$. We suggest that a detailed characterization of monogenetic versus central vent eruptions in combination with simple models has the potential to provide important constraints on both the time-evolving melt influx and size/geometry of crustal plumbing at active volcanic centers. 
MODELING MAFIC LAVA FLOWS WITH AN EYE TO EMERGENCY RESPONSE. L. P. Keszthelyi ${ }^{1}$ ${ }^{1}$ Astrogeology Science Center, U.S. Geological Survey (2255 N. Gemini Dr., Flagstaff, AZ 86001; laz@usgs.gov).

Introduction: Models that estimate the extent of lava flows from a volcanic eruption can be useful in planning for the emergency response to a future volcanic eruption in the American Southwest. In particular, they can help determine the extent to which experiences in Hawai'i can be relied on. However, the models all have limitations that must be wellunderstood before they are used to make decisions that affect the life and well-being of people.

Here, two key questions are considered. (1) How far can a lava flow be expected to reach? And (2) When will it be safe to begin reconstruction efforts after a lava flow has covered an area? The second is easier to anwer and is addressed first.

Lava Flow Cooling: Reopening roads covered by lava flows usually starts with removing some part of the lava flow with heavy earth-moving equiptment. In Hawai'i, the tracks on a bulldozer were damaged when this was attempted on a solidified but still hot lava flow. The time required to cool a typical lava flow to a safe temperature, say below $70^{\circ} \mathrm{C}$ or $160^{\circ} \mathrm{F}$, is of the order of years. This time is primarily controlled by the thickness of the lava flow and the amount of rainfall.

If the cooling is primarily by conduction of heat through an insulating crust of lava, then the time is proportional to the square of the lava flow thickness (double the thickness $=4$ times the time to cool) [1] However, if there is substantial cooling by rain, this rule is violated and the flow cools more linearly (double thickness $=2$ times the time to cool). Rain can be a very important effect on the wet side of Hawai'i, but should be negligible in the American Southwest.

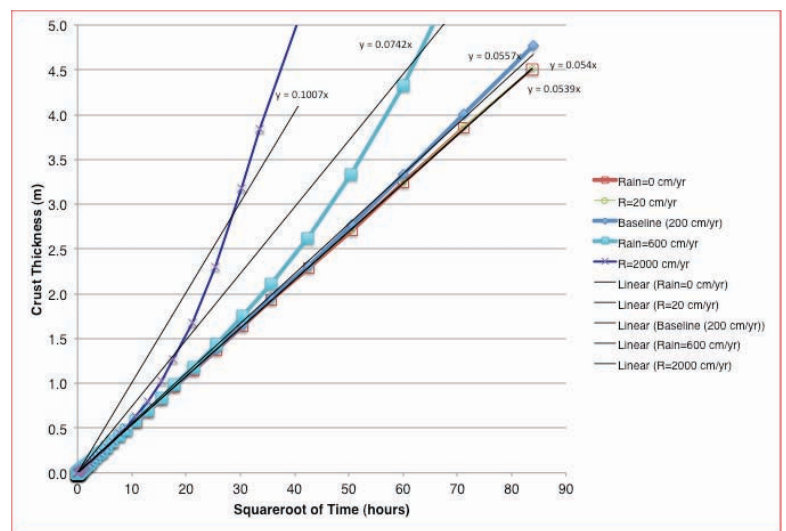

Figure 1: model calculations for the thickness of a pahoehoe crust on a basaltic lava flow for various rainfall rates. Straight lines indicate cooling dominated by conduction with little effect from rain. Model is based on $[2-3]$.
The take-home message from this analysis is that it can easily take a decade or more for a typical lava flow to naturally cool to a safe temperature. This time can be greatly shortened by pouring large amounts of water onto the flow (inundate with the equivalent of a few times the thickness of the lava flow).

Modeling the Length of Lava Flows: There are many models, some very simple, that purport to establish a relationship between the final length of a lava flow and a few basic parameters about the lava and/or the eruption. Despite their apparent pedigree in terms of numbers of peer-reviewed papers using them, no generic model can be trusted.

In the broadest sense, lava flows stop when they solidify too much to flow. Thus a balance between the heat (a) being added by new lava coming out of the ground and (b) being lost out of the lava flow should allow a generic model for how long a lava flow can be [4]. The problem is that how lava flows loose their heat is very different between open flows and insulated flows and between sheet flows and narrow tubes/channels [5]. Within each basic type of lava flow, there are some empirical relationships that relate parameters such as erupted volume, effusion rate, lava viscosity, and slope to the length of the flow.

While such semi-generic models can give a rough sense of what to expect, individual lava flows can behave in very unpredicted manners. For example, the direction that a lava flow takes is generally downhill. However, topographic obstacles only a fraction the height of the final lava flow can substantially divert the flow. Perhaps more problematic for accurate prediction is the fragility of the lava transport conduits. Even short-lived (hours to days) stoppages or surges in lava flux can irreparably damage lava tubes or channels in difficult to predict locations [6-7]. This essentially resets the location of the lava vent to a new location along the existing tube/channel. Since the total erupted volume is a key element in estimating the final length of a lava flow, there is no practical way to predict the length of a lava flow before the eruption ends.

References: [1] Hon K. et al. (1994) GSA Bull., 106, 351-370. [2] Keszthelyi L. and Denlinger R. (1996) Bull. Volcanol., 58, 5-18. [3] Keszthelyi L. and McEwen A. S. (1997) GRL, 24, 2463-2466. [4] Griffiths R. W. (2000) Annu. Rev. Fluid Mech., 32, 477518. [5] Keszthelyi L. et al. (2006) J. Geol. Soc. Lon., 163, 253-264. [6] Kauahikaua et al. (2003) USGS Prof. Pap. 1676, 63-88. [7] Crisp J. and Baloga S. M. (1994) JGR, 99, 1819-1831. 


\title{
Relationship between dike and volcanic condiut distribution in a highly eroded monogenetic volcanic field: San Rafael, Utah
}

\author{
Koji Kiyosugi ${ }^{1}$, Charles Connor ${ }^{1}$, Paul Wetmore ${ }^{1}$, Brian Ferwerda ${ }^{1}$, Aurelie Germa ${ }^{1}$, Laura \\ Connor $^{1}$ and Amanda Hintz ${ }^{2}$ \\ * presenting author \\ ${ }^{1}$ Department of Geology, University of South Florida, Tampa, Florida \\ ${ }^{2}$ Utah Geological Survey, Salt Lake City, Utah
}

A relatively young, potentially active monogenetic volcanic field (Black Rock Desert, Utah) and a relatively old, eroded sub-volcanic plumbing system composed of dikes and sills (San Rafael Swell, Utah) were examined for patterns of conduit distribution and validity of statistical methods to perform probabilistic hazard assessments on monogenetic volcanic fields globally. We mapped 63 conduits, 2000 dike segments, and 12 sills in the San Rafael sub-volcanic field, where this Pliocene magmatic system is eroded to a depth of $\sim 0.8 \mathrm{~km}$ and is exceptionally well exposed. Although the number of mapped conduits, dikes, and sills might represent minimums, depending on the level of erosion and exposure, mapped dikes are more numerous around the areally extensive sills and interact with sills and conduits in complex ways. We analyze conduit distribution using kernel density methods and compare results with dike and sill distribution. We find that the distribution of conduits matches the major features of dike distribution, including development of clusters and distribution of outliers. These statistical models are then applied to the distributions of volcanoes in several recently active volcanic fields, where intrusion distributions must be inferred from very sparse data, and compared with San Rafael conduit distribution. This comparison supports the use of statistical models in probabilistic hazard assessment for distributed volcanism. Specifically, renewed dike intrusion and potential eruptions in active basaltic systems can be assessed probabilistically from the distribution of older volcanoes in dispersed volcanic systems. 


\section{Capabilities of University of Utah Seismograph Stations for Monitoring Seismicity in Utah}

KOPER, Keith D., koper@seis.utah.edu, University of Utah Seismograph Stations; Kristine L. Pankow; Relu Burlacu; Katherine M. Whidden; James C. Pechmann; J. Mark Hale; Paul M. Roberson

The University of Utah Seismograph Stations (UUSS) monitors seismicity in Utah using data from a network of 253 seismograph stations deployed in Utah and neighboring states. These stations generate 786 channels of seismic data from various combinations of broadband, strongmotion, and short-period sensors. UUSS processes the incoming data in near real time, with nearly all events larger than M 3 automatically detected, located, and publicized within 10 minutes of the origin time. Most earthquakes occur within Intermountain Seismic Belt (ISB), a 100- to 200-km-wide band of seismicity that extends southward into Arizona and northward into Montana; however, a significant number of small, mining-induced earthquakes occur within the coal-mining belt of central Utah. The current uniform detection threshold for the network is estimated to be M 1.5 within the ISB in Utah and M 2.0 to 2.5 elsewhere in the state. In an average year in Utah, UUSS locates one earthquake of M 4 or larger, 12 of M 3-4, 200 of M 2-3, 1200 of M 1-2, and 300 of M 0-1. An M 5 or larger earthquake occurs on average every 5 years, although the last such event was in 1992. The ISB and its associated faults are responsible for most of the seismic hazard and risk in Utah, which is concentrated along the five central segments of the Wasatch fault in the northern Utah Wasatch Front urban corridor and along the Hurricane fault in southwestern Utah.

Three features of UUSS operations are especially relevant to monitoring potential volcanism in Utah. The first is that UUSS routinely computes full moment tensors for Utah seismic events larger than about M 3.5. This includes statistical tests to assess the significance of any isotropic component that appears in the solution. This capability was developed because of the need to identify and model mine collapses, which are not purely deviatoric, and would be seamlessly applicable to dilatational volcanic sources. Second, UUSS currently maintains a network of 8 infrasound arrays across Utah, with continuous telemetry to the UUSS data center. Three UUSS personnel have expertise in infrasound analysis and would be able to process and interpret any infrasonic signals generated by volcanic activity. Third, UUSS maintains approximately 6 portable seismograph stations that could be deployed by UUSS technicians to most regions of Utah within approximately 24 hours. Therefore, once unusual volcanic activity had been identified, UUSS could quickly augment the permanent network in the region of interest. 


\title{
InSAR mapping of Holocene volcanoes in the western conterminous U.S. - preliminary results
}

\author{
Z. Lu ${ }^{1}$, C.Y. Zhao ${ }^{2}$, W.J. Lee ${ }^{2}$, L.Y. Ji ${ }^{2}$, M. McLay ${ }^{1}$, and D. Dzurisin ${ }^{1}$ \\ 1) USGS/CVO, Vancouver, WA 98607 (lu@usgs.gov); \\ 2) Visiting scholars at USGS/CVO, Vancouver, WA 98607.
}

We have processed ERS, Envisat, and ALOS PALSAR radar images to map long-term ground surface deformation from 1992 through 2010 at about 25 volcanoes in the western conterminous US that have erupted during the Holocene. We have used multi-temporal radar images and averaged many interferometric synthetic aperture radar (InSAR) images to improve the signal-tonoise ratio of our deformation analysis. Our preliminary results indicate persistent subsidence over Medicine Lake volcano and Lassen volcanic center at a rate of $\sim 1 \mathrm{~cm} /$ year, but no significant deformation at the other volcanoes. Deformation fields driven by geothermal exploration or development and large earthquakes have also been identified near several of the volcanoes. Our results represent the first attempt to systematically map deformation over Holocene volcanoes in the western conterminous U.S. and will be updated regularly with future radar acquisitions. 


\title{
Pondering the consequences of an eruption in the American Southwest: Challenges for emergency management and scientific response
}

\author{
Christina Neal, U.S. Geological Survey, Alaska Volcano Observatory
}

4230 University Drive

Anchorage, AK 99508

tneal@usgs.gov tel 907-786-7458

The last volcanic eruption in the Four Corners region of the American Southwest occurred 1000 years ago. Today, even a modest eruption within the range of plausible events has potential to threaten lives and property, disrupt economic activity and lifelines, and impact the environment, possibly for years. Hazards of concern span a large range of classic volcanic phenomena with the added potential for large-scale forest fires, something of special concern in the arid Southwest. While the exact time and place of the next eruption are unknown, it will with certainty pose new and complex challenges to responding agencies, particularly because very few residents or official responders living in the region today have first-hand knowledge of eruptions and associated hazards.

Volcanic crises can have protracted and erratic precursory periods that demand heightened vigilance over long periods of time (weeks, months, years). Especially where monitoring is skeletal and baselines are lacking, a significant challenge for responders is to communicate useful information despite significant uncertainties about the probability of an eruption, as well as its timing, size, severity, and duration. At the same time, the web of federal, state, and local agencies, universities, and the private sector may have overlapping spheres of response. Plans that clarify roles and protocols are vital to avoid conflicting messages. While public safety and mitigation of impacts are primary objectives of planning, plans should also consider critical science opportunities and outline mechanisms to facilitate a strategic research response to episodes of volcanic unrest or eruption.

Any eruption in the American Southwest would unleash a deluge of attention, severely taxing the resources and capabilities of scientific agencies, law enforcement, emergency management, and land managers. Strain will be magnified if the period of unrest and eruption continues for months or years, interspersed with pauses of variable duration. The Internet, 24/7 news cycle, exploding social media and future incarnations of surveillance and communication technology will complicate and enhance the ability of agencies to manage the situation in ways difficult to anticipate.

Preparing for volcanic eruptions in the Southwest necessarily competes with higher probability hazards such as drought and wildfire. Given the small likelihood of an eruption in the lifetime of a typical interagency response plan, what investment in planning and preparation for a volcanic crisis is reasonable? At what scale should such planning occur? Can these efforts be dovetailed with other natural hazard assessment and risk mitigation efforts to leverage scarce resources? Discussions at this meeting will begin answering these questions by identifying probable eruption scenarios, impacts, current response protocols, and critical gaps in science and preparedness. 


\author{
Abstract \\ Volcanism in the American Southwest \\ October 18-20, 2012 \\ Flagstaff, AZ
}

Osiensky, Jeffrey M. ${ }^{1}$, Birch, Scott ${ }^{2}$

${ }^{1}$ NOAA/NWS Alaska Region Anchorage, AK ${ }^{2}$ NOAA/NWS Western Region Salt Lake City, UT

\title{
Volcanic ash plumes and its impact to aviation in the Western United States
}

Volcanic eruption plumes and drifting ash clouds from Western U.S. volcanoes have caused aviation concerns and delays in flight operations nationwide. A jet cruising through an ash plume can encounter a wide variety of impacts ranging from surface and windscreen abrasion to engine flameout, depending on the material encountered and exposure. Large volcanic eruptions in the Pacific Northwest and California have the potential to transport ash into the Southwestern United States. In addition to the airborne ash hazard to aviation there exists another hazard, namely ash fallout on the ground. Volcanic threat areas in southern California from the Long Valley Caldera to the Salton Buttes pose a direct risk to public health and infrastructure in the Southwest U.S.

There are many volcanic ash hazards to aviation and the public. This paper will explain the hazards and what is being done both nationally and internationally to mitigate the threat of volcanic ash. Federal, state and local agencies are working together to better understand the hazards and find the best ways to deal with them. State and local emergency responders will be the folks who deal with the impacts from the volcanic ash and need to know what resources are available to assist in their decision making process.

The question is not "if" but "when" will the next volcanic ash event take place which impacts the Southwestern U.S.? In order to be prepared, there needs to be a plan in place which outlines the roles and responsibilities of the local, state and federal agencies involved. In addition, there needs to be training and frequent collaboration to ensure proficiency in dealing with such a low frequency, high impact event. 
Abstract for: Volcanism in the American Southwest, October 18-20, Flagstaff, AZ

Spatial Database of Holocene and Latest Pleistocene Volcanic Vents in the Western Conterminous U.S. By David W. Ramsey and Connie L. Driedger

The U.S. Geological Survey (USGS) National Volcano Early Warning System (NVEWS) has identified 28 volcanoes and volcanic centers in the western conterminous U.S. as posing moderate, high, or very high threats to surrounding communities based on their recent eruptive histories and their proximity to vulnerable people, property, and infrastructure. To better understand the extent of potential hazards at these and other volcanoes and volcanic centers, the USGS Volcano Science Center (VSC) is compiling a spatial database of all known Holocene and Latest Pleistocene volcanic vents in the western conterminous U.S. The database records vent location (latitude/longitude coordinates), vent type (cinder cone, maar, etc.), lithology, age, geographic feature name, mapping source, and, where available, spatial database source. USGS geologic maps, USGS Data Series, the Smithsonian Global Volcanism Program (GVP) catalog, and published journal articles are the main data sources cited. Locations in this compilation can be spatially compared to located earthquakes, used as generation points for numerical hazard models or hazard zonation buffering, and analyzed for trends in regional magmatism and more localized eruptive activity through time. The spatial database will eventually be available online as a USGS Data Series publication. 
Experimental determination of $\mathrm{H}_{2} \mathrm{O}$ and $\mathrm{CO}_{2}$ solubility in basalt and basaltic andesite Kurt Roggensack $^{1}$ and Gordon Moore ${ }^{2}$

${ }^{1}$ School of Earth and Space Exploration, Arizona State University, Tempe, AZ 852871404 (kurt.roggensack@asu.edu)

${ }^{2}$ Department of Chemistry, Arizona State University, Tempe, AZ 85287-1604; now at Earth and Environmental Sciences, University of Michigan, Ann Arbor, MI 48109 (gmmoore@umich.edu)

$\mathrm{H}_{2} \mathrm{O}$ and $\mathrm{CO}_{2}$ are the most abundant volatiles in mafic magmas and their solubility influences volcanic degassing and the eruptive process. A series of piston-cylinder experiments have been conducted to investigate $\mathrm{H}_{2} \mathrm{O}$ and $\mathrm{CO}_{2}$ solubility of mafic compositions commonly found in olivine-hosted melt inclusions. The starting material used in experiments are natural samples, a basalt from a Guatemalan cinder cone and a basaltic andesite from Fuego volcano, Guatemala. The samples were crushed and melted twice in a gas-mixing furnace at NNO to produce crystal-free, homogeneous glass prior to experimentation. All experiments were volatile-saturated with either pure $\mathrm{H}_{2} \mathrm{O}$ or a mixed $\mathrm{H}_{2} \mathrm{O}-\mathrm{CO}_{2}$ fluid in $\mathrm{Au}_{80} \mathrm{Pd}_{20}$ capsules and heated with a graphite furnace to $1190{ }^{\circ} \mathrm{C}$ at pressures from 300 to $600 \mathrm{MPa}$. The intrinsic $\mathrm{fO}_{2}$ of our piston-cylinder assembly is $\mathrm{NNO}+1$. The analysis of the run products includes low-temperature, vacuum manometry of the residual $\mathrm{H}_{2} \mathrm{O}$ and $\mathrm{CO}_{2}$ fluid, electron microprobe analysis of the glass and FTIR spectroscopy of $\mathrm{H}_{2} \mathrm{O}$ and $\mathrm{CO}_{2}$ in the glass. Pressure calibration of the piston-cylinder is based on the solubility of $\mathrm{H}_{2} \mathrm{O}$ and $\mathrm{CO}_{2}$ in rhyolite. Among successful experiments, only those capsules with accurate fluid analysis (i.e. measurement of both $\mathrm{CO}_{2}$ and $\mathrm{H}_{2} \mathrm{O}$; sensible mass balance) were included in the final data set. Our results improve upon $\mathrm{H}_{2} \mathrm{O}$ $\mathrm{CO}_{2}$ solubility of basalt and now allow distinction between $\mathrm{H}_{2} \mathrm{O}-\mathrm{CO}_{2}$ solubility of basaltic andesite. At similar experimental conditions water and $\mathrm{CO}_{2}$ solubility are greater in basalt as compared to basaltic andesite. At $300 \mathrm{MPa}$ with a pure $\mathrm{H}_{2} \mathrm{O}$ fluid the solubility of water in basalt is $6.3 \mathrm{wt} . \%$ versus $5.2 \mathrm{wt} . \%$ for basaltic andesite (based on near-IR molar absorptivities of Dixon et al., 1994 and those calculated from Mandeville et al. 2002, respectively). Direct comparison of our $\mathrm{CO}_{2}$ solubility results is simplified by interpolation of fugacity- $\mathrm{CO}_{2}$ abundance. Our experiments indicate that a pure $\mathrm{CO}_{2}$ fluid at $300 \mathrm{MPa}$ (i.e. $\mathrm{CO}_{2}$ fugacity of 5945 bars) would equilibrate with $2,500 \mathrm{ppm} \mathrm{CO}_{2}$ in basalt and 2,000 ppm $\mathrm{CO}_{2}$ in basaltic andesite (molar absorptivity calculated from Dixon \& Pan, 1995). At these same conditions the SolEx model predicts $\sim 1,500 \mathrm{ppm} \mathrm{CO}_{2}$ in basalt, whereas the Papale et al. (2006) model predicts 3,300 $\mathrm{ppm} \mathrm{CO}_{2}$ for basalt. In conclusion, our results show that there is a significant compositional dependence on $\mathrm{H}_{2} \mathrm{O}$ $\mathrm{CO}_{2}$ solubility in basalts and basaltic andesites with solubilities being greater in more mafic compositions. These data with complete characterization of gas fugacity will improve our ability to accurately interpret melt inclusion suites and model degassing processes. 


\title{
Scenario for an eruption in the San Francisco Peaks or similar volcanic field: Effects on Northern Arizona and beyond
}

\author{
Stephen Self \\ Office of Nuclear Material Safety and Safeguards, US-Nuclear Regulatory Commission, Washington DC 20555, \\ USA; stephen.self@nrc.gov [also at Dept. of Earth and Environmental Sciences, The Open University, UK]
}

There is a chance of an explosive basaltic volcanic eruption in the foreseeable future from one of the 20-30 monogenetic volcano fields in the SW United States that have been active within the past 100,000 years. It could be an eruption from fields in SW Nevada or California, or from the Black Rock Desert Field of SW Utah or the Raton Volcanic Field of New Mexico, or from the local San Francisco Volcanic Field (SFVF), Arizona, to name but a few. Both dry (magmatic) and wet (phreatomagmatic, i.e., involving groundwater) eruptions have occurred in these volcanic fields in recent geologic times.

An interpretation of the style, duration, and effects of a dry eruption can be based on the AD 1085 eruption of Sunset Crater, the youngest eruption from the SFVF. Results from on-going studies on the deposits of this eruption could serve as a scenario for planning in case of future volcanic events. Sunset's deposits suggest it was the largest recent eruption from a monogenetic basaltic volcano field in the continental US, and one of the most explosive, meaning that it spread pyroclastic scoria and ash fall-out deposits over a wider area than in many similar eruptions. The duration of activity is not known precisely but can be bracketed between a few weeks to perhaps 2-3 years. Notable features of significance to hazards are: the 10-km-long eruptive fissure on which Sunset scoria cone grew; the relatively large eruptive magmatic volume (almost $\left.1 \mathrm{~km}^{3}\right)$ apportioned between the broad $(\sim 2-\mathrm{km}$ wide, 300-m-tall) Sunset scoria cone, the scoria-and-ash fall deposit, and three lava flows (maximum $11 \mathrm{~km}$ long); and the widespread dispersal of some scoria fall units. In another volcanic field in SW Nevada evidence from Lathrop Wells cone and fall deposits $(\sim 75,000$ years old $)$ suggest an eruptive style that was equally explosive and yielded some layers of finer ash deposits than seen at Sunset.

In terms of hazard scenario planning, the main facts to be considered for this style of explosive volcanism are:

- The main phase may last intermittently for last months to years, with declining activity dwindling on for several more years.

- Eruption clouds laden with ash could reach altitudes up to $16 \mathrm{~km}$ above the volcano ( $\sim 60,000 \mathrm{ft})$ while spreading up to $100 \mathrm{~s} \mathrm{~km}$ downwind, affecting flying aircraft. There would be ash impacts on local airports, on flights crossing the region at $\sim 35000 \mathrm{ft}$, and on aircraft heading in and out of ABQ, LVA, PHX, and SLC airports, dependent on wind-directions.

- Ash fall-out deposit areas may be $>500 \mathrm{~km}^{2}$ for $10 \mathrm{~cm}$ thickness of ash and up to $1000 \mathrm{~s} \mathrm{~km}^{2}$ for $\sim 1$ $\mathrm{cm}$. Despite this, there would be only a trace of fine ash fall-out beyond N Arizona for an eruption from SFVF, again dependent on wind-directions. Surface-wind-induced re-distribution of ash could also occur for months to years after the eruption has finished. Ash causes disruptions to surface transport systems and many services, is an abrasive nuisance, and in suspension can cause respiratory problems. However, basaltic ash is not recognized to carry minerals that cause severe health hazards. - On the longer term there may be ash-deposit-induced changes in soil properties, such as moisture, dependent on the location of the next eruption and the local geologic setting.

This talk also reflects the work of many colleagues working on the Sunset and related deposits, including Michael Ort, Amanda Clarke, Fabrizio Alfano, Chelsea Allison, Greg Valentine, and, of course, Bob Amos. The views expressed are those of the author and not of the US-NRC. 
The View from Social Science:

How people will think and behave during an extended crisis with large uncertainties

Katherine F. Thompson, Columbia University Center for Research on Environmental Decisions

As scientists who are accustomed to interpreting probabilities, margins of error, and other statistical uncertainties, seismologists and volcanologists may well feel that such precise, scientific presentations of data are the most accurate formats through which to communicate information to the public when a potential volcanic crisis threatens.

Probabilities may seem like a natural format to use-after all, many Americans use weather forecast information on a near-daily basis. But research shows that a surprising percentage of the population critically misunderstands statements like, "there is a 30\% chance of rain tomorrow." Other psychology studies show us that people tend to systematically misinterpret, ignore, distort, or misuse probability information, even when given clear verbal guidelines about the meaning of the numbers that they're seeing. ${ }^{2-5}$

This talk will introduce several psychological biases and tendencies that may affect the way the public understands (or even whether they pay attention to) the kind of information that might be provided by scientists or emergency managers during an extended period of volcanic unrest in the American Southwest. In addition to systematic distortions in probability perception, this talk will address:

- why long time horizons make people unlikely to act: ${ }^{6}$

- how the "finite pool of worry" can cause us to ignore environmental dangers; ${ }^{7}$

- how learning probabilities through personal experience (sampling) results in very different decisions than learning from verbal descriptions (summary statistics); ${ }^{3}$

- how hedonic reappraisal, or adjusting to the "new norm," may interfere with warnings or evacuation orders; ${ }^{8}$

- and how critically important it is that people perceive instrumentality: the idea that their actions can and will have an effect on their situation. ${ }^{9}$

Although many psychological biases tend to work against people's willingness to invest in preparation and mitigation measures, those practitioners who understand the social science behind hazard warnings and information campaigns can easily avoid common pitfalls, and at times even harness some of these biases to improve the public's ability to understand and use warning information.

\section{References}

1. Gigerenzer, G., Hertwig, R., Van Den Broek, E., Fasolo, B., \& Katsikopoulos, K. V. (2005). "A 30\% chance of rain tomorrow": How does the public understand probabilistic weather forecasts? Risk Analysis, 25(3), 623629.

2. Kahneman, D. \& Tversky, A. (1979). Prospect Theory: An Analysis of Decision under Risk. Econometrica, XLVII: 263-291.

3. Hertwig, R., \& Erev, I. (2009). The description-experience gap in risky choice. Trends in Cognitive Science, 13(12), 517-523.

4. Lichtenstein, S., Slovic, P., Fischhoff, B., Layman, M., \& Combs, B. (1978). Judged frequency of lethal events. JEP: Human Learning and Memory, 4, 551-578.

5. Budescu, DV, Weinberg, S \& Wallsten, TS (1987). Decisions based on numerically and verbally expressed uncertainties. Journal of Experimental Psychology: Human Perception and Performance, 14(2), 281-294.

6. Trope, Y., \& Liberman, N. (2011). Construal level theory. In P. Van Lange, A. W. Kruglanski, and E. T. Higgins (Eds), Handbook of Theories of Social Psychology. London: Sage Publications.

7. Hansen, J., Marx, S., \& Weber, E. U. (2004). The role of climate perceptions, expectations, and forecasts in farmer decision making: IRI.

8. Brickman, P., \& Campbell, D. T. (1971). Hedonic relativism and planning the good society. In M. H. Appley (Ed.), Adaptation level theory: A symposium (pp. 287-302). New York: Academic Press.

9. Spence, A., Poortinga, W., Butler, C., \& Pidgeon, N. F. (2011). Perceptions of climate change and willingness to save energy related to flood experience. Nature Climate Change, 1(1), 46-49. 


\title{
Basaltic volcanism in the American Southwest over the last million years: what happens here, how often, and why?
}

\author{
Greg Valentine ${ }^{1}$ and Michael Ort ${ }^{2}$ \\ ${ }^{1}$ Department of Geology, 411 Cooke Hall, University at Buffalo, Buffalo, NY 14260 \\ ${ }^{2}$ SESES, Box 4099, Northern Arizona University, Flagstaff, AZ 86011
}

The southwestern United States has over forty volcanic fields containing $\sim 1400$ Quaternary basaltic volcanoes. The volcanoes within the fields are predominantly monogenetic, each having produced only one eruptive episode that might last for days to years. The majority of Quaternary eruptions in the Southwest have occurred along a northwest-southeast-trending band that stretches from the Potrillo field in southern New Mexico, through four fields in Arizona, to the Lunar Crater field in Nevada (Figure 1); these six fields account for $2 / 3$ of the Quaternary events. Most of the remaining volcanoes occur around the margins of the Basin and Range Province, although a few are in the interior of the Province or scattered outside of it. The level of detailed study varies markedly from field to field, suggesting that a concerted hazards-oriented program of characterization and modern geochronology would be useful. The average interval between monogenetic eruptions in the entire region, based upon existing data, is $\sim 700$ 1000 years, depending upon whether one focuses on events $<50 \mathrm{ka}$ or on the last $2 \mathrm{Ma}$, and is comparable to the repose intervals between eruptive episodes at individual intermediate-composition stratovolcanoes. The potential hazards, while appreciable, are less extensive than at a reawakening stratovolcano, but assessment is complicated by the fact that a new eruption could occur at an unknown location within a broad area with widely varying land use patterns.

Conceptual models of volcanic field behavior in the Southwest range from large scales, which relate volcanism to rift zones, lithosphere-upper mantle coupling around the Colorado Plateau margins, deformation-induced focusing of pre-existing melts in lithospheric mantle, and shear-driven upwelling of asthenosphere. At smaller scales, the location of individual volcanoes and clusters is related to crustal structure and, it is

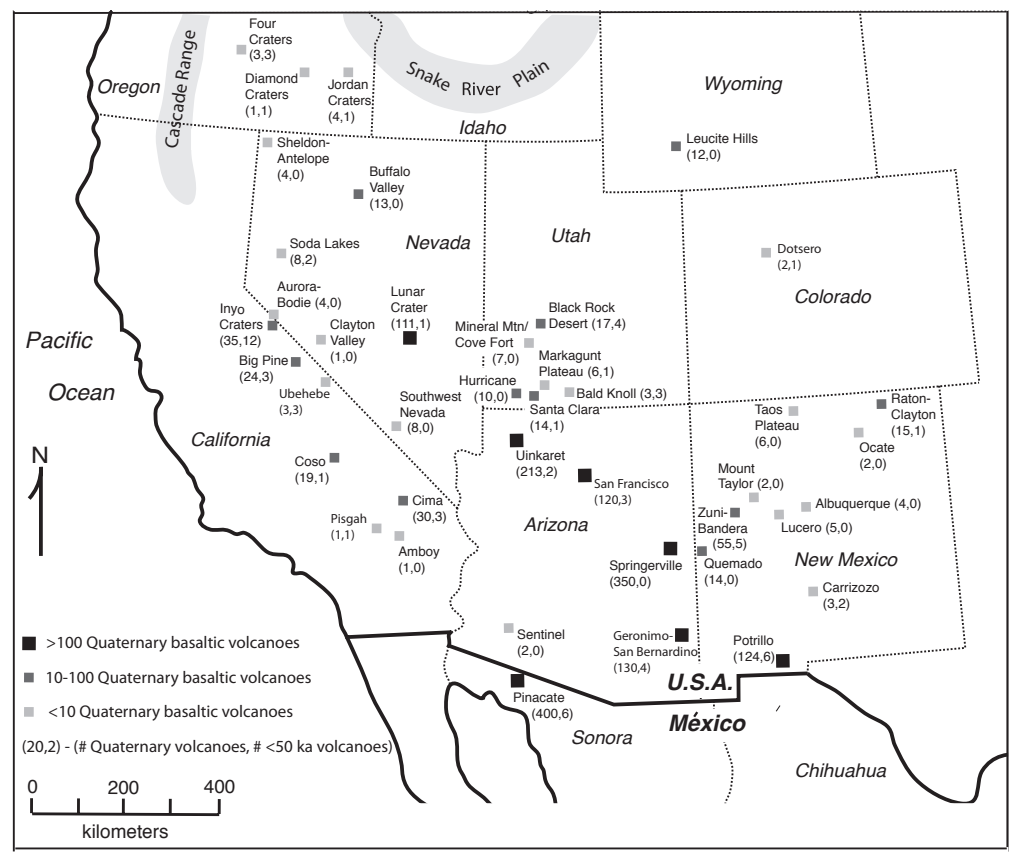
hypothesized, to small-scale compositional heterogeneities in source mantle material. Geochemical and petrologic data suggest that many eruptions are fed by magmas that rose quickly through the crust with little or no stalling, which implies that the lead time from monitoring might be relatively short (weeks?), if precursor signals are detected at all. Given the wide area with the potential for eruptions and its generally low population density, choosing where to monitor on an ongoing basis is problematic. Remote sensing using satellites, perhaps using InSAR, may be the best option for monitoring over such a large area. Recent work indicates that explosive basaltic eruptions with extensive ash-laden plumes might be common. Although often assumed to be relatively benign, eruptions at small-volume volcanoes can exhibit a range of styles (including phreatomagmatic) and produce all of the hazard types (tephra plumes, tephra fall, pyroclastic density currents, ballistics, lava flows, shock waves, and modification of landscapes and sediment budgets) that can occur at other types of volcanoes. 
Timing of late Pleistocene volcanism at Big Pine volcanic field: insights from volcanic stratigraphy, cosmogenic ${ }^{36} \mathrm{Cl}$ dating, and paleomagnetism.

\author{
J.A. Vazquez ${ }^{1}$, J.M. Woolford ${ }^{2}$, Alana Zohar ${ }^{2}$, E.A. Nagy-Shadman ${ }^{3}$, D.E. Champion ${ }^{1}$ \\ 1. US Geological Survey, Menlo Park, CA \\ 2. California State University, Northridge \\ 3. Pasadena City College
}

The Big Pine volcanic field (BPVF) is one of several Quaternary volcanic fields located along the tectonically active Owens Valley of eastern California. Previous geochronology establishes an 1.3 Ma history of volcanism at BPVF, but the ages and distribution of volcanic products associated with the youngest eruptions are poorly resolved. To delimit the timing and products of the youngest volcanism at BPVF, we combine field mapping, cosmogenic ${ }^{36} \mathrm{Cl}$ dating, and paleomagnetism of lavas and pyroclastic deposits in the area surrounding the town of Aberdeen where basaltic lavas with well-preserved flow structures and morphology are concentrated. Mapping and petrography reveal that approximately fifteen vents and six principal flow fields occur in the Aberdeen area. Discrete basalt units are distinguishable using phenocryst-xenolith composition and mode, and overlapping flow margins establish the relative ages of most of the flows. For cosmogenic ${ }^{36} \mathrm{Cl}$ dating, samples were taken from pahoehoe flow surfaces, near-vent tumuli, and the tops of meter-scale accretionary lava balls. Using the scaling model of Desilets and Zreda (2003) and assuming erosion rates of $<3 \mathrm{~mm} / \mathrm{ka}$, ${ }^{36} \mathrm{Cl}$ exposure ages for lava flows from the top, middle, and bottom of the volcanic stratigraphy are ca. $15 \mathrm{ka}, 25 \mathrm{ka}$, and $40 \mathrm{ka}$, suggesting multiple episodes of late Pleistocene volcanism. These ages agree with cosmogenic ${ }^{3} \mathrm{He}$ and ${ }^{40} \mathrm{Ar} /{ }^{39} \mathrm{Ar}$ ages from previous studies, and are relatively insensitive to choice of scaling model or erosion rate. Samples from the three stratigraphically youngest flows, which cover much of the area south of Taboose Creek and north of Division Creek, yield ${ }^{36} \mathrm{Cl}$ ages of ca. $15 \mathrm{ka}$. This youngest episode of volcanism erupted olivine to plagioclase-pyroxene phyric basalt from at least four vents along the Sierran front and separated by up to $5 \mathrm{~km}$. Paleomagnetic directions for the lavas are consistent with the distinct episodes of volcanism implied by the ${ }^{36} \mathrm{Cl}$ ages. The youngest lavas yield nearly indistinguishable paleomagnetic directions, suggesting that the youngest episode may have erupted compositionally diverse basalt over decadal to centurial timescales. The young ${ }^{36} \mathrm{Cl}$ ages and high concentration of vents relative to other areas of BPVF indicate that late Pleistocene volcanism has migrated to the west-central portion of the volcanic field. 


\title{
Data compiled by the Smithsonian about volcanoes in the southwestern United States
}

\author{
Edward Venzke (Global Volcanism Program, Smithsonian Institution)
}

A database of volcanoes with Holocene activity, referred to as the Volcanoes of the World (VOTW) database, is maintained by the Smithsonian's Global Volcanism Program (GVP). The role of GVP is to compile data about volcanoes world-wide, providing a standardized and accessible source of information that can be used by a wide range of researchers, officials, and the public. Referenced sources are varied, but material is primarily extracted from published research papers.

There are 10 volcanoes from the states of Nevada, Utah, Colorado, Arizona, and New Mexico (table 1) thought to have been active in the last 10,000 years. Data collected includes the basics of location, elevation, primary name, synonyms, feature names, morphological type, and captioned photographs. GVP staff also writes a paragraph summarizing the geological and volcanological history of each volcano. All known eruptions are listed, with dates (when available), location and deposits, and types of eruptive events.

Three of the ten volcanoes have no dated eruptions, but are believed by researchers to be Holocene based on other evidence. Another six have only one dated eruption each in the Holocene. Zuni-Bandera has two eruptions known, at $1170 \mathrm{BCE} \pm 300$ years and $8710 \mathrm{BCE} \pm 300$ years. In addition, there are another 28 volcanic areas that were active in the Pleistocene epoch; two of those, Steamboat Springs (Nevada) and Valles Caldera (New Mexico), have exhibited recent fumarolic activity.

The GVP database schema has recently been redesigned in a variety of ways to allow increased flexibility and the ability to compose complex search queries. Submissions of new research findings are always welcome from the volcanological community to improve and expand the database.

Table 1. List of Holocene volcanoes in Nevada, Utah, Colorado, Arizona, and New Mexico. Last known eruption, primary morphological type, new VOTW 4.0 volcano numbers, and legacy volcano numbers (as previously published) and are shown.

\begin{tabular}{|l|l|c|c|c|c|}
\hline \multicolumn{1}{|c|}{ Name } & \multicolumn{1}{|c|}{ State } & $\begin{array}{c}\text { Last Known } \\
\text { Eruption }\end{array}$ & $\begin{array}{c}\text { Primary Volcano } \\
\text { Type }\end{array}$ & $\begin{array}{c}\text { Volcano } \\
\text { Number }\end{array}$ & $\begin{array}{c}\text { Legacy } \\
\text { VNum }\end{array}$ \\
\hline Soda Lakes & Nevada & Unknown & Maars & 326010 & $1206-01-$ \\
\hline Santa Clara & Utah & Unknown & Volcanic field & 327010 & $1207-01-$ \\
\hline Bald Knoll & Utah & Unknown & Cinder cones & 327030 & $1207-03-$ \\
\hline Markagunt Plateau & Utah & $<=1050$ CE & Volcanic field & 327040 & $1207-04-$ \\
\hline Black Rock Desert & Utah & 1290 CE \pm 150 & Volcanic field & 327050 & $1207-05-$ \\
\hline Dotsero & Colorado & 2200 BCE \pm 300 & Maar & 328010 & $1208-01-$ \\
\hline Uinkaret Field & Arizona & 1100 CE \pm 75 & Volcanic field & 329010 & $1209-01-$ \\
\hline Sunset Crater & Arizona & 1075 CE \pm 25 & Cinder cone & 329020 & $1209-02-$ \\
\hline Carrizozo & New Mexico & 3250 BCE \pm 500 & Cinder cones & 327110 & $1210-01-$ \\
\hline Zuni-Bandera & New Mexico & 1170 BCE \pm 300 & Volcanic field & 327120 & $1210-02-$ \\
\hline
\end{tabular}




\title{
Uncertainties regarding explosive maar-diatreme eruptions within volcanic fields
}

\author{
James White, University of Otago, Dunedin, New Zealand
}

Maar-diatreme volcanoes are small volcanoes having a central crater cut into the ground surface and surrounded by a tuff ring. Buried beneath the crater floor is a deep vent structure filled with debris, called a diatreme. Basaltic eruptions produce maar-diatreme volcanoes when groundwater fuels explosions in the subsurface. Initial explosions occur at shallow depths, while many later explosions occur deeper within the sub-crater diatreme structure, contributing to growth of the diatreme but not necessarily adding material to the tuff ring surrounding the syn-eruptive crater.

Observed maar-forming eruptions at Taal and Tarawera both began with weakly explosive growth of scoria cones, with explosive maar excavation beginning later in the eruptions when laterally propagating dikes intersected groundwater in a way that produced explosive magmawater interaction. In contrast, many other small volcanoes in volcanic fields show evidence that initial eruptions involved explosive magma-water interaction and excavation of substrate country rock, but that as the eruptions continued explosivity declined and eruption style changed to produce scoria cones and lava flows that buried the initial crater.

Despite decades of attention and careful laboratory work on magma-water explosions, there remain significant gaps in our knowledge of the precise conditions that facilitate explosive magma-water interactions in real eruptions. There is a known ratio of magma to water that has maximum potential for generation of vapor from magmatic heat, and hence maximum explosive potential, which is often expressed as an optimal magma:water mass ratio of $\sim 3: 1$. The ratio is simply that at which all water can be vaporized while cooling the magma to the vaporization temperature. Both experiments and observations of eruptions in water show, however, that this ratio has little or no relationship to the quantities of magma and water that are available at the site of an eruption.

It is known that in laboratory experiments with basalt, a small trigger is needed to initiate explosive magma-water interaction, but the nature and scale of equivalent triggering requirements for natural systems are not known. Laboratory studies show that interaction of magma with clay-water slurries differs qualitatively from its interaction with clear water, and though there is good geological evidence that slurries such as liquefied sediment are encountered in eruptions, how they affect magma-water explosivity is not understood.

In summary, magma interacting with groundwater is needed to form basaltic maar-diatremes, but neither the magma-supply conditions, nor the characteristics of the aquifer, that are needed to produce these explosive eruptions are sufficiently well understood to support confident prediction of whether, and when, a dike transiting an aquifer will drive explosive phreatomagmatic eruptions. This implies that when assessing potential hazard of a new eruption in a volcanic field with groundwater, it should be assumed that eruptions may begin with violent magma-water explosions, and also that even initially quiet eruptions may subsequently become violent if conditions change to initiate magma-water explosions. 


\title{
Petrogenetic Processes in the Lunar Crater Volcanic Field, Nevada
}

\author{
E. Widom ${ }^{1 *}$, C. Rasoazanamparany ${ }^{1}$, G.A. Valentine ${ }^{2}$, E.I. Smith ${ }^{3}$, J.A. Cortes ${ }^{2}$, D. \\ Kuentz ${ }^{1}$, R. Johnsen ${ }^{3}$ \\ ${ }^{1}$ Department of Geology, Miami University, Oxford, USA, widome@ muohio.edu (*presenting author) \\ ${ }^{2}$ Department of Geology, State University of New York, Buffalo, USA, gav4@buffalo.edu \\ ${ }^{3}$ Department of Geoscience, University of Nevada, Las Vegas, USA, gene.smith@unlv.edu
}

The Lunar Crater volcanic field, Nevada, is located in the central Great Basin at the northern end of a NNE-trending belt of Pliocene to Quaternary mafic volcanism. The volcanic field contains $>200$ vents, including cinder cones, tuff rings and maars, with eruptive activity as recently as $\sim 40 \mathrm{ka}[1]$. Our studies are investigating the petrogenetic processes leading to compositional variations within single monogenetic eruptions, as well those of closely spaced monogenetic vent clusters, with a focus on the relative roles of mantle source heterogeneity, variable degrees of partial melting and fractional crystallization, and shallow lithospheric assimilation. In this context, we have analyzed $\sim 20$ relatively high-MgO (7-11\%) basalts/trachybasalts from four volcanic centers in the northern LCVF: the Marcath volcano, which is the youngest in the volcanic field, and three other volcanoes referred to as YMB (younger megacryst-bearing), OPB (older phenocryst-bearing), and PB (plagioclase-bearing) [2] that are located within $\sim 500 \mathrm{~m}$ of one another and $\sim 6 \mathrm{~km} \mathrm{NE}$ of Marcath. Major element variations within the sample suite indicate that the magmas are compositionally distinct, although the Marcath and YMB samples may be related to one another by fractional crystallization of olivine, clinopyroxene, and minor plagioclase and Fe-Ti oxide. Trace element variations further delineate two distinct compositional endmembers, both of which have OIB-type characteristics: the OPB/PB group which is broadly similar to HIMU with $\mathrm{Nb}-\mathrm{Ta}$ enrichment and LILE depletion; and the Marcath/YMB group with overall higher abundances of highly incompatible trace elements and enrichments in $\mathrm{Cs}, \mathrm{Rb}$ and $\mathrm{Ba}$ similar to EMI. Isotopic analyses reveal a limited range in $\mathrm{Nd}$ and $\mathrm{Hf}$ isotope ratios, but significant variations in $\mathrm{Sr}$ and $\mathrm{Pb}$ isotopes, and superchondritic $\mathrm{Os}$ isotopic signatures. The samples exhibit a strong negative correlation between $\mathrm{Sr}$ and $\mathrm{Pb}$ isotopes that could be attributed to lower crust assimilation. However, the lack of correlation of isotopic signatures with indices of fractionation, and high (OIB-like) $\mathrm{Nb} / \mathrm{U}$ ratios that exhibit a positive correlation with ${ }^{187} \mathrm{Os} /{ }^{188}$ Os argue against an important role for either upper or lower crustal assimilation. Instead, the trace element and isotopic data support a model in which the basalts are generated by partial melting of an enriched and heterogeneous mantle source, with variable degrees of mixing between HIMU and EMI-type endmembers. The OPB/PB group magmas have HIMU-like trace element patterns and Sr$\mathrm{Pb}$ isotope signatures that are consistent with derivation from a mantle source containing a component of ancient recycled oceanic crust. The Marcath/YMB group samples, which exhibit comparatively high $\mathrm{Ba}, \mathrm{Rb}$ and $\mathrm{Cs}$, lower ${ }^{206} \mathrm{~Pb} /{ }^{204} \mathrm{~Pb}$, and higher ${ }^{87} \mathrm{Sr} /{ }^{86} \mathrm{Sr}$, are derived from an EMI-like mantle source that may have been generated by recycled oceanic crust plus a minor sediment component [3]. These results indicate that the mantle in this region is characterized by chemical and isotopic heterogeneity over very small spatial scales, likely related to ancient subduction processes.

[1] Shepard et al. (1996) Geology 23, 21-24; [2] Valentine et al. (2011) EOS Fall AGU V33C-2657;

[3] Rasoazanamparany et al. (2012) Goldschmidt Conference, Montreal. 
Postcaldera magmatism at three Rio-Grande-rifted calderas: Implications for assessing volcanic hazards at active caldera systems in the USA

Matthew J. Zimmerer ${ }^{(1)}$ and William C. McIntosh ${ }^{(1)}$

(1) - New Mexico Bureau of Geology and Mineral Resources, New Mexico Institute of Mining and Technology, Socorro, NM 87801, USA

Understanding the timing and duration of postcaldera magmatism is important for assessing potential hazards at active caldera systems. Ages of postcaldera volcanic and plutonic rocks from three Rio-Grande-rift faulted caldera shed light on the timescales of postcaldera magmatism. Rio Grande rifting has exposed intracaldera sequences and silicic intrusions at the Organ caldera (southern NM), the Questa caldera (northern NM), and the Mt. Aetna caldera (central CO). Exposures at these systems allow for assessing the timescales of postcaldera magmatism not possible at younger, less-dissected active calderas. In general, ages indicate that postcaldera volcanism began immediately (within analytical error) after the caldera-forming event and continued for several $100 \mathrm{ka}$ to several Ma. Postcaldera intrusions were emplaced concurrently with postcaldera volcanism, but intrusive activity continued for several Ma after volcanism ceased. Thermochronology of exposed intrusions indicates reheating events as much as $10 \mathrm{Ma}$ younger than the caldera forming event, suggesting that subcaldera environments may act as pathways for much younger and perhaps unrelated magmatism. At these three systems postcaldera magmatism was concentrated within or along caldera faults, though some magma was emplaced and erupted several kilometers outside of the caldera margins.

Volcanic deposits from the Yellowstone, Long Valley, and Valles calderas crop out in the western USA. The probability of a catastrophic caldera-forming eruption from these Quaternary systems is extremely low. More probable volcanic hazards are small volume lava flows and pyroclastic eruptions associated with postcaldera domes. Considering our research on the midTertiary Rio-Grande-rifted calderas and the youthful nature of these Quaternary systems, postcaldera magmatism at these three calderas is likely to continue for several $100 \mathrm{ka}$ to several Ma. A protracted period of subcaldera magma emplacement without an accompanying volcanic eruption is also expected at these three Quaternary systems. Additional work focusing on the durations of postcaldera magmatism, the recurrence intervals between postcaldera eruptions, and the relationships between post- and syncaldera volcanism is necessary to develop a comprehensive understanding of the hazards associated with postcaldera magmatic activity. 


\title{
Volcanism in the American Southwest
}

October 18-19, 2012

\author{
Meeting Location: \\ U.S. Geological Survey \\ 2255 North Gemini Drive \\ Flagstaff, AZ 86001
}

Meeting Purpose: Bring together volcanologists, network operators, land managers, and emergency managers to start a conversation about southwestern volcanoes and identify how to best prepare for future activity.

Organizers: Jake Lowenstern, Laz Kestay, SAFRR Project: Science Application for Risk Reduction (Sue Perry and John Bwarie) all from USGS; Nelia Dunbar NMBGMR; Greg Valentine, University at Buffalo, Michael Ort, Northern Arizona University

\section{Meeting Outcomes:}

- Communicate who would be responsible for what during a crisis

- Communicate the roles and limitations of USGS

- Communicate the roles of other federal agencies (NOAA, FAA, military)

- Raise understanding of resources available to state and local EM

- Use discussion panels to determine what else could be needed (e.g., regional plans regular ongoing activities, etc.)

- Increase awareness of volcanism and vulnerabilities in the American Southwest.

- Ponder eruption probabilities in regions with rare, distributed, volcanism.

\section{October 18, 2012}

7:45-8:00 “Registration", coffee, etc.

8:00-8:10 Introduction to the Flagstaff Campus and meeting logistics Laz Kestay, and Jake Lowenstern, both at USGS

8:10-8:30 Self-introductions, facilitated (Name, agency, relevant responsibilities)

8:30-9:00 Pondering the consequences of a volcanic eruption in the American Southwest: Tina Neal, USGS

9:00-9:30 Scenario for an eruption in the San Francisco Peaks Volcanic Field: Effects on Northern Arizona and beyond: Steve Self, NRC 
9:30-10:00 Volcanism in the American Southwest over the last million years: What happens here, how often, and why? Greg Valentine, University at Buffalo and Michael Ort, Northern Arizona University

10:00-10:20 BREAK (10:18 is GREAT ARIZONA SHAKEOUT!).

10:20-10:50 From the trenches: Anecdotes from actual eruptions and crises in the US and abroad. John Ewert, USGS

10:50-11:20 Scenarios for eruptions in New Mexico: Valles Caldera, Taos, ZuniBandera, etc.: Nelia Dunbar, New Mexico Bureau of Geology and Mineral Resources

11:20-11:50 Seismic and other networks in the southwest: How would we monitor volcanic unrest? Paul Earle, USGS

Lunch (11:50-13:10):

13:10-13:40 An Introduction to incident response and the Incident Command System: Ellis Stanley, Dewberry

13:40-14:40 3 Minute Presentations (Sixteen poster presenters give quick overviews of what they'll show at their poster)

14:40-15:40 Poster session: Attendees circulate through the first 12 posters.

Coffee served during poster session

15:40-16:10 Eruption potential and hazard, Valles Caldera, New Mexico: Fraser Goff, Ret., Los Alamos National Laboratory

16:10-17:10 Panel Discussion: Incident Response in the context of volcanic unrest in AZ, NM, UT: Incorporating science into decisions for public safety: Lou Trammell, Director of AZDEM, Robert Rowley, Coconino County; Alan Sinclair, BIA; Ellis Stanley, Dewberry; Wendy Blackwell, NMDHSEM

17:10-17:40 Capstone Talk: Impact of Sunset Crater eruption on prehistoric groups in Northern Arizona: Lessons on human adaptation to disasters: Mark Elson, Desert Archaeology, Inc.

17:40 Adjourn for Day. Dinner on your own. 


\section{Day 2 October 19, 2012}

8:00-8:30 Small group planning: identifying challenges of Southwest volcanism.

8:30-9:00 The view from social science: How people will think and behave during an extended crisis with large uncertainties: Katherine Thompson, Columbia University

9:00-9:30 Monitoring dike intrusions with GPS networks: Past experience and future potential: Bill Hammond, University of Nevada, Reno

9:30-10:00 3 Minute Presentations (8 final posters)

10:00-10:20 Break

10:20-11:20 Panel Discussion: Seismic and geodetic monitoring in the southwest: What do networks need to do and to provide? Panel members Keith Koper, UU; Paul Earle, USGS; Bill Hammond, UNR; David Brumbaugh, NAU; Rick Aster, New Mexico Tech

11:20-11:50 Volcanic ash plumes and their impact to aviation in the Western United States: Jeff Osiensky and Scott Birch, NOAA/National Weather Service

11:50-13:00 Lunch

13:00-14:00 Discussion: What (if anything) should we do next?

14:00-14:10 Volcano Readiness Wrap-Up John Bwarie, USGS SAFRR

\section{AFTERSESSION: SOUTHWEST VOLCANO PROBABILITIES}

14:10-14:40 Modeling mafic lava flows with an eye to emergency response ( $L a z$ Kestay, USGS)

14:40-15:45 Poster session: Attendees circulate through the day's posters.

Coffee served during posters.

15:45-16:45 Panel Discussion: Geology, geochronology, and probabilistic modeling of volcanism in the U.S. Interior (Greg Valentine, U. Buffalo; Bill McIntosh, NMT; Duane Champion, USGS; Chuck Connor, U. S. Florida; Jorge Vazquez, USGS) 
16:45-17:15 Overview of the field trip for 10/20: Michael Ort, Nancy Riggs, Northern Arizona University)

Adjourn

Day 3 October 20, 2012

Optional field trip to Sunset Crater National Monument 